This document is the accepted manuscript version of the following article:

Joseph, J., Luster, J., Bottero, A., Buser, N., Baech1i, L., Sever, K., \& Gessler, A. (2021). Effects of drought on nitrogen uptake and carbon dynamics in trees. Tree Physiology, 41(6), 927-943. https://doi.org/10.1093/treephys/tpaa146

\title{
2 Effects of drought on nitrogen uptake and carbon dynamics
}

\section{3 in trees}

4 Jobin Joseph ${ }^{1}$, Jörg Luster ${ }^{1}$, Alessandra Bottero ${ }^{1}$, Nathalie Buser ${ }^{2}$, Lukas Baechli ${ }^{1}$, Krunoslav

5 Sever $^{3}$, and Arthur Gessler ${ }^{1,4^{*}}$

$6 \quad{ }^{1}$ Forest Dynamics, Swiss Federal Institute for Forest, Snow and Landscape Research WSL,

7 Zürcherstrasse 111, 8903 Birmensdorf, Switzerland;

8 'Universitätsklinik für Hals, Nasen- und Ohrenkrankheiten Kopf- und Halschirurgie

9 Freiburgstrasse-16, 3010, Bern; Switzerland

$10{ }^{3}$ Department of Forest Genetics, Dendrology and Botany, Faculty of Forestry, University of

11 Zagreb, Svetošimunska cesta 25, 10000 Zagreb, Croatia

$12{ }^{4}$ Institute of Terrestrial Ecosystems, ETH Zurich, 8092 Zurich, Switzerland

14 *corresponding author: Swiss Federal Institute for Forest, Snow and Landscape Research 15 WSL, Zürcherstrasse 111, 8903 Birmensdorf, Switzerland; email: arthur.gessler@wsl.ch; phone: +41447392 818

\section{Summary}

Research on drought impact on tree functioning is focused primarily on water and carbon (C) dynamics. Changes in nutrient uptake might also affect tree performance under drought and there is a need to explore underlying mechanisms. We investigated effects of drought on a) in-situ nitrogen (N)-uptake accounting for both, $\mathrm{N}$ availability to fine-roots in soil and actual $\mathrm{N}$-uptake, b) physiological $\mathrm{N}$-uptake capacity of roots, and c) the availability of new assimilates to fine roots influencing the $\mathrm{N}$-uptake capacity using ${ }^{15} \mathrm{~N}$ and ${ }^{13} \mathrm{C}$ labelling. We assessed saplings of six different tree species (Acer peudoplatanus, Fagus sylvatica, Quercus petraea, Abies alba, Picea abies, Pinus sylvestris). 


\section{Introduction}

\section{Key words}

Drought resulted in significant reduction of in-situ soil $\mathrm{N}$-uptake in deciduous trees accompanied by reduced carbon allocation to roots and by a reduction in root biomass available for $\mathrm{N}$-uptake. While physiological root $\mathrm{N}$-uptake capacity was not affected by drought in deciduous saplings, reduced maximum ammonium but not nitrate uptake was observed for A.alba and P.abies.

Our results indicate that drought has species-specific effects on $\mathrm{N}$-uptake. Even water limitations of only 5 weeks as assessed here can decrease whole plant inorganic Nuptake independent of whether the physiological $\mathrm{N}$-uptake capacity is affected or not.

Carbon; Climate change; Coniferous; Deciduous; Drought; Forest ecosystem; Nitrogen; Nutrient allocation; Plant-soil continuum; Stable isotopes

Forest ecosystems are known to be at present strong terrestrial carbon (C) sinks (Lal, 2005). They thus can play a significant role in mitigating the effects of global warming by absorbing atmospheric $\mathrm{CO}_{2}$ and retaining it in the plant-soil continuum for long. Climate change has, however, the potential to turn forests during drought periods from $\mathrm{C}$ sinks into sources on large spatial scales (Ciais et al., 2005; Graf Pannatier et al., 2012; Sun et al., 2006; Unger et al., 2010). On the long-term, drought-induced forest mortality that is reported to increase worldwide (Allen et al., 2010) might continuously decrease C-sequestration in forests (Anderegg et al., 2016; Breshears and Allen, 2002). The major mechanisms discussed to be involved in drought-induced loss of tree functioning and finally mortality are hydraulic failure (mainly due to a disruption of water transport by xylem cavitation) and $C$ starvation (Mcdowell et al., 2008; McDowell, 2011; Sevanto et al., 2014) together with damages by biotic attacks (Manion, 1981).

In addition to the adverse impacts on $\mathrm{C}$ assimilation and tree hydraulics, drought might lead also to reduced nutrient uptake resulting in nutrient imbalances in trees and ecosystems (Kreuzwieser and Gessler, 2010). Especially impaired nitrogen (N) uptake is assumed to 
deteriorate general metabolic function and cell structural integrity and to cause also negative feedbacks on the $C$ balance (Gessler et al., 2017). Under drought, the depletion of free amino acids in tree leaves resulted in degradation of Rubisco in beech and oak saplings (Fotelli et al., 2002; Hu et al., 2013), indicating that amino acids needed for basic cellular functions were synthesized at the expense of photosynthetic potential. At the same time, reduced $\mathrm{N}$ supply increases the sensitivity of stomata to leaf water potential leading to stomatal closure and thus reduces $C$ assimilation (Ghashghaie and Saugier, 1989). As a consequence, $N$ uptake and its reduction by reduced water availability is also an important parameter affecting tree performance under drought.

While impaired $\mathrm{N}$ uptake by trees during drought events lasting from weeks to a growing season might be a result of lower ion mobility, reduced microbial nutrient delivery (i.e. soil related processes), plant physiological processes might be also directly involved (Fotelli et al., 2002). Moreover, it has been shown for adult beech and spruce that transpiration driven transport of nutrients in the xylem is related to nutrient net uptake with lower transpiration rates resulting in lower uptake (Gessler et al., 2002). In addition, reduced carbon supply to the roots as a result of drought induced photosynthetic or transport restriction (Sala et al., 2010) leads to a lower availability of recent assimilates and thus energy for active $\mathrm{N}$ uptake and assimilation as well as to restricted root growth and delivery of carbon to rhizosphere microorganisms (Gessler et al., 2017). The impairment of carbon allocation to the roots might, however, depend on drought intensity: Moderate drought has been shown to increase root growth and belowground C allocation in beech and oak (Leuschner et al., 2001, adult beech and oak; Hommel et al. 2016, beech saplings), whereas intensive and longer-lasting drought events reduce the availability of recent assimilates to the roots (Hagedorn et al., 2016, beech saplings).

Under field conditions, a long-term reduction of soil water availability over years together with increased air temperature had a strong impact on $\mathrm{N}$ uptake kinetics leading to lower maximum uptake rates in adult beech (Gessler et al., 2005). Under the same soil water reduction and high light availability, whole plant uptake of inorganic $\mathrm{N}$ was also reduced in beech saplings (Fotelli et al. 2004). For both, adult trees and saplings, it is, however, not clear if physiological impairment of root functioning or reduced overall growth rates that might have reduced nutrient demand lead to reduced uptake rates. 
89 Amongst soil mineral nutrients, $\mathrm{N}$ is an abundantly required macro-nutrient for tree growth

90 and maintenance and is also most likely the limiting nutrient for tree growth under future

91 high tropospheric $\mathrm{CO}_{2}$ concentrations in natural ecosystems not strongly affected by anthropogenic $\mathrm{N}$ deposition (Lukac et al., 2010; Reich et al., 2006). $\mathrm{N}$ plays a central role in photosynthesis, is as key component of proteins involved in all metabolic processes in plant cells and also in regulating stomatal conductance (Sun et al., 2016). In the soil, $\mathrm{N}$ is available to tree roots as inorganic nitrate and ammonium and also in its organic form as amino acids. Even though direct absorption of organic $\mathrm{N}$ by the trees roots has been reported especially in temperate and boreal forests, inorganic sources of $\mathrm{N}$ constitute the major part of the $\mathrm{N}$ taken up by temperate tree species (Liu et al. 2017; Dion et al., 2018). Trees are able to store significant amounts of $\mathrm{N}$ (Millard and Grelet, 2010), which allows them to temporally uncouple $\mathrm{N}$ demand and external $\mathrm{N}$ supply. This is mainly important in spring, when growth of foliage and roots cannot be met by recently assimilated N (Millard \& Proe, 1992; Gessler et al., 1998). In later spring and summer, however, $\mathrm{N}$ demand is mainly met by root uptake from the soil (Millard and Proe, 1992) and thus any reduction of $\mathrm{N}$ uptake during drought periods might negatively affect tree functioning thus potentially impair the resistance and resilience capacity of forest ecosystems (Gessler et al., 2017).

107 With the present work, we aimed at exploring the effects of moderate and severe drought on

108 the in situ uptake of inorganic N by different deciduous (Acer pseudoplatanus, Fagus sylvatica,

109 Quercus petraea) and coniferous (Picea abies, Abies alba, and Pinus sylvestris) tree species

110 taking into account the combined effect $\mathrm{N}$ availability to the fine roots in the soil and actual

$111 \mathrm{~N}$ uptake. We have chosen the two lifeform types (deciduous, coniferous) because of their 112 differences in $\mathrm{N}$ storage and transport (Gessler et al. 1998). Within life-forms, drought

113 susceptibility is assumed to differ among species with $Q$. petraea being the least sensitive 114 among the deciduous (Scherer et al. 2011) and A. alba among the coniferous species 115 (Bouriaud \& Popa, 2008). Moreover, we studied drought effects on the $\mathrm{N}$ net uptake kinetics 116 and thus the direct effects of drought on the physiological root uptake capacity. For in situ 117 uptake we determined ${ }^{15} \mathrm{~N}$ incorporation into the tissues of the saplings growing in soil were 118 the ammonium and nitrate pools had been ${ }^{15} \mathrm{~N}$ labelled. For assessing uptake kinetics, roots 119 of the six species still attached to the tree where incubated in solutions with different 
concentrations of ${ }^{15} \mathrm{~N}$ nitrate or ammonium to determine the concentration-dependent net

121 uptake rates (Gessler et al., 2004).

122 To assess the influence of the availability of recent assimilates on root $\mathrm{N}$ uptake capacity, we 123 linked ${ }^{15} \mathrm{~N}$ uptake to carbon allocation belowground by tracking the fate of ${ }^{13} \mathrm{C}$ labelled 124 assimilates in drought exposed as well as in girdled saplings.

126 We tested the following hypothesis:

127 1) N uptake by tree roots is reduced under severe drought due to both reduced physiological 128 uptake capacity and reduced ion mobility and thus $\mathrm{N}$ availability to the roots.

129 2) The availability of new assimilates to fuel the active transport and to provide carbon for $130 \mathrm{~N}$ assimilation influences the $\mathrm{N}$ uptake capacity. Under moderate drought, an increase in 131 belowground $\mathrm{C}$ allocation might occur, resulting in an increased $\mathrm{N}$ uptake capacity.

\section{Materials and methods}

\section{Experimental design - drought and girdling treatments}

134 In total three experiments were performed in greenhouse or climate chamber settings. One 135 experiment (experiment $i$ ) was conducted to characterize the influence of drought stress on 136 soil processes (e.g. mobility and thus availability of $\mathrm{N}$ for root uptake) and actual ${ }^{15} \mathrm{~N}$ uptake 137 by the trees. In experiment ii) ammonium and nitrate net uptake kinetics and thus the direct 138 effects on the physiological root uptake capacity was examined. In experiment i) the relationship between $\mathrm{N}$ uptake and the allocation of recent ${ }^{13} \mathrm{C}$ labelled assimilates within the plant was additionally determined. In an additional experiment iii), we aimed at analyzing if $\mathrm{N}$ uptake capacity can get restricted as a result of reduced carbon supply (without any additional impacts of drought on root functioning) to the roots by performing a girdling experiment. On

In experiments i) and ii) two-year-old saplings of $A$. pseudoplatanus, F. sylvatica, Q. petraea,

$146 P$. abies, A. alba, and P. sylvestris were used. Plants were obtained from the nursery of the experimental garden of the Swiss Federal Research Institute WSL and later transferred to 5L pots filled with commercial soil (Ökohum $\mathrm{GmbH}$; see Table S1) with a pH value of 5.5 and grown in the greenhouse. Average air temperature and relative air humidity $(\mathrm{RH})$ during the 
experiment were $22.7 \pm 4.5^{\circ} \mathrm{C}(\mathrm{SD})$ and $67 \% \pm 16 \%$, respectively (Fig. S1). Supplement light

151 provided a constant $16 \mathrm{~h}$ light period and average daytime photosynthetic photon flux density 152 was $69.62 \pm 61 \mu \mathrm{mol} \mathrm{m} \mathrm{m}^{-2} \mathrm{~s}^{-1}$.

153 After leaves of all deciduous species had been fully developed, trees in both experiments 154 were exposed to two drought levels (severe and moderate drought) for approximately 5 weeks while in the control treatment plants were watered to field capacity. Volumetric water content (VWC) was determined continuously with soil moisture sensors (Decagon EC 5,

157 California, USA) and irrigation was adjusted so that the moderate drought treatment reduced soil water content on average to $11.0 \pm 3.3 \%$ and severe drought to $5.5 \pm 3.8 \%$. In the wellwatered controls VWC was on average $15.7 \pm 2.7 \%$ (Fig. S2, Table S2). Soil specific pF curves (obtained from Hyprop (DIN EN ISO 11274; Fig. S3) by UMS GmbH) allowed to convert VWC to soil water potential (Kirste and Durner, 2018). The severe drought resulted in a soil water potential range between -0.6 and $-1.2 \mathrm{MPa}$ and thus close to the permanent wilting point (1.5 MPa) (Farrick et al., 2019) and the moderate drought ranged between -0.2 to -0.6 MPa. Stem diameter and height measurements were done before and during drought stress periodically for monitoring tree growth. ${ }^{15} \mathrm{~N}$ uptake. In experiment i) the transport of recently ${ }^{13} \mathrm{C}$ labelled assimilates was assessed as described in the section "Experimental design - N uptake and carbon supply".

For experiment iii) we used two-year-old saplings of $F$. sylvatica and P. sylvestris grown in a climate chamber. Air temperature and $\mathrm{RH}$ were set to $20^{\circ} \mathrm{C}$ and $65 \%$, respectively.

171 Illumination was provided by daylight fluorescent lamps (Osram Fluora L58W/77, Osram $172 \mathrm{GmbH}$, Munich, Germany) plus incandescent light bulbs (Osram Krypton $60 \mathrm{~W}$ ). 173 Photosynthetic photon flux density (PPFD) at the top of the trees was $250 \mu \mathrm{mol} \mathrm{m}^{-2} \mathrm{~s}^{-1}$. Half

174 of the trees was girdled (i.e. the bark with the phloem was removed around the stem to 175 prevent basipetal phloem transport) at a stem height of $3 \mathrm{~cm}$ above the soil surface. These 176 trees were grown under well-watered conditions for 5 weeks as were the controls. ${ }^{13} \mathrm{C}$ 177 allocation to the roots as well as $\mathrm{N}$ uptake were assessed as described in the section "Experimental design - $\mathrm{N}$ uptake and carbon supply". 
In all experiments (i)-iii)) pre-dawn leaf water potential (UPD, MPa) and leaf-level gas

181 exchange (light saturated photosynthesis $\left(A_{s a t}, \mu \mathrm{mol} \mathrm{CO} \cdot \mathrm{m}^{-2} \cdot \mathrm{s}^{-1}\right)$, stomatal conductance $\left(\mathrm{g}_{\mathrm{s}}\right.$, $\left.182 \mathrm{mmol} \mathrm{H}_{2} \mathrm{O} \cdot \mathrm{m}^{-2} \mathrm{~s}^{-1}\right)$ and transpiration $\left(\mathrm{E}, \mathrm{mmol} \mathrm{H}_{2} \mathrm{O} \cdot \mathrm{m}^{-2} \mathrm{~s}^{-1}\right)$ ) were measured once per week during the drought or girdling treatments. Leaf water potential (LWP) was determined with a Scholander bomb (Model 600, PMS Instrument Company, Oregon, USA). For gas exchange measurements carried out with a GFS 3000 system (Heinz WALZ GmbH, Effeltrich, Germany) temperature and air humidity were set to $20^{\circ} \mathrm{C}$ and $65 \%$, respectively. $\mathrm{CO}_{2}$ concentration was $400 \mathrm{ppm}$ and photosynthetically active photon flux density was $1500 \mu \mathrm{mol} \mathrm{m}^{-2} \mathrm{~s}^{-1}$.

\section{Experimental design - $\mathrm{N}$ uptake and carbon supply}

190 Experiment i): To characterize the combined effects of soil and root uptake processes we added ${ }^{15} \mathrm{~N}$ labelled ammonium nitrate $\left(99 \%-{ }^{15} \mathrm{NH}_{4}{ }^{15} \mathrm{NO}_{3}\right)$ in solution directly to the soil as described in detail by Gockele et al. (2014) with five replicates per species and treatment. We added $35 \mathrm{mg} / \mathrm{kg}$ soil of $99 \%-{ }^{15} \mathrm{NH}_{4}{ }^{15} \mathrm{NO}_{3}$ to make sure not to increase the plant available inorganic $\mathrm{N}$ concentration by more than $3 \%$ to avoid fertilization effects (Total $\mathrm{KCl}$-extractable (Gessler et al. 2005) inorganic $\mathrm{N}$ (i.e. $\mathrm{NO}_{3}{ }^{-}$and $\mathrm{NH}_{4}{ }^{+}$) amounted to approx. $15 \mathrm{mmol} \mathrm{N} / \mathrm{kg}$ soil). The ${ }^{15} \mathrm{NH}_{4}{ }^{15} \mathrm{NO}_{3}$ was applied by the end of $3^{\text {rd }}$ week of the drought period (Fig. 1) via holes predrilled to a depth of $5 \mathrm{~cm}$ in an equidistance $(3 \mathrm{~cm})$ grid over the pot surface. $50 \mathrm{ml}$ of 40 millimolar ${ }^{15} \mathrm{NH}_{4}{ }^{15} \mathrm{NO}_{3}$ solution per pot was injected into the holes through a four-side port needle allowing optimal vertical distribution of the label connected to a dispenser (see Gockele et al., 2014). This procedure was applied to avoid adding high amounts of water and at the same time allowed optimal distribution of the tracer. Five days after ${ }^{15} \mathrm{~N}$ labelling, we applied a ${ }^{13} \mathrm{CO}_{2}$ pulse label to trace the new assimilates through the plants. For ${ }^{13} \mathrm{C}$ labelling we constructed a temporary gas tight transparent plastic chamber to expose the plant with ${ }^{13} \mathrm{C}$ enriched $\mathrm{CO}_{2}$ generated by mixing $1 \mathrm{M} \mathrm{Na}_{2}-{ }^{13} \mathrm{CO}_{3}\left(98 \%,{ }^{13} \mathrm{C}\right)$ and $1 \mathrm{M} \mathrm{Na}_{2}-{ }^{12} \mathrm{CO}_{3}\left(98 \%,{ }^{12} \mathrm{C}\right)$ at a 50:50 ratio with $1 \mathrm{M} \mathrm{H}_{2} \mathrm{SO}_{4}$ inside a conical flask kept outside the chamber. The ${ }^{13} \mathrm{C}-\mathrm{CO}_{2}$ was then directed into the chamber via a pump (N5KP18, M\&C TechGroup, Ratingen, Germany) for 3 hours and fans inside the chamber ensured proper mixing. The ${ }^{13} \mathrm{CO}_{2}$ concentration was continuously measured using an Off-Axis Integrated cavity output spectrometer (LGR -CCIA 36d, LosGatos research, CA, USA) (Fig. S4). Ten days after the ${ }^{13} \mathrm{C}$ pulse (i.e. after five weeks of drought), plants were harvested and separated into fine roots, 
$212{ }^{13} \mathrm{C}$ isotopic composition. All tissues were oven-dried $\left(65^{\circ} \mathrm{C}\right)$ and ${ }^{15} \mathrm{~N}$ and ${ }^{13} \mathrm{C}$ uptake was based

213 on dry mass.

214

215 Experiment ii): To assess $\mathrm{N}$ uptake kinetics, we incubated roots in nutrient solutions (Gessler 216 et al., 2005). For these experiments three replicates per species, treatment and nitrate or 217 ammonium concentration were used. After 5 weeks of drought (see Fig. 1), roots where 218 carefully excavated from the soil and while they were still attached to the tree, incubated in 219 solutions with different concentrations with either $99 \%{ }^{15} \mathrm{~N}$ nitrate or $99 \%{ }^{15} \mathrm{~N}$ ammonium 220 added. Five concentration levels were chosen according to Gessler et al., (2005) and the range 221 for ammonium was 1 to $200 \mu \mathrm{mol} \mathrm{L}^{-1}$ and for nitrate 1 to $500 \mu \mathrm{mol} \mathrm{L^{-1 }}$. A nutrient solution 222 containing $\mathrm{K}^{+}(769 \mathrm{mmol} / \mathrm{L}), \mathrm{Na}^{+}(431 \mathrm{mmol} / \mathrm{L}), \mathrm{Ca}^{2+}(662 \mathrm{mmol} / \mathrm{L}), \mathrm{HPO}_{4}{ }^{-}\left(319 \mathrm{mmol} / \mathrm{L}^{2}, \mathrm{SO}_{4}{ }^{2-}\right.$ 223 (320 mmol/L), $\mathrm{Mg}^{2+}(190 \mathrm{mmol} / \mathrm{L}), \mathrm{Cl}^{-}(201 \mathrm{mmol} / \mathrm{L})$, and $\mathrm{Zn}^{2+}(14.6 \mathrm{mmol} / \mathrm{L})$ was also added 224 at a concentration of $(0.1 \mathrm{ml} / \mathrm{L})$ to the incubation solution to reach concentrations values of natural forest soil solutions (Gessler et al., 1998). After incubating roots for 2 hours, fine roots (incubated into the solutions and a short section outside the solution; see Gessler et al. (2004)) were harvested, washed with demineralized water, weighted, oven dried at $65^{\circ} \mathrm{C}$ and ground for analysis of $\mathrm{C}$ and $\mathrm{N}$ content, and ${ }^{15} \mathrm{~N}$ isotopic composition. By fitting uptake rates (based on the fine root fresh weight to allow comparison with previous literature (e.g. Gessler

230 et al., 2005)) versus concentrations applying a Michaelis-Menten model, the kinetic parameter $\mathrm{V}_{\max }$ (maximum net uptake capacity, based on length and biomass of the incubated roots) and $\mathrm{k}_{\mathrm{m}}$ (nitrate or ammonium concentration where $50 \%$ of the maximum net uptake is observed) were determined as described in detail by Gessler et al. (2005). We acknowledge that our approach is only an approximation as the Michaelis-Menten model can be-sensu stricto-only applied to unidirectional reactions, while $\mathrm{N}$ net uptake consists of an influx and an efflux term.

Experiment iii): 25 days after the start of the girdling treatment a ${ }^{13} \mathrm{CO}_{2}$ pulse (see Fig. 1) was applied as described for experiment i) with 5 replicates. After ten days, we excavated roots and incubated the fine roots for 2 hours in nutrient solutions with $500 \mu \mathrm{mol} \mathrm{L} \mathrm{L}^{-1}{ }^{15} \mathrm{~N}$ nitrate as described for experiment ii). Then plants were harvested (and root were washed with demineralised water) and separated into different organs and tissues (fine roots, coarse roots, stem, leaves/needles). After drying at $65^{\circ} \mathrm{C},{ }^{13} \mathrm{C}$ isotope composition was determined 
244 in all tissues and ${ }^{15} \mathrm{~N}$ was analysed in the incubated fine roots. ${ }^{15} \mathrm{~N}$ and ${ }^{13} \mathrm{C}$ incorporation was 245 based on dry weight.

\section{${ }^{15} \mathrm{~N}$ and ${ }^{13} \mathrm{C}$ analysis and uptake calculations}

248 To determine $\mathrm{N}$ and $\mathrm{C}$ content and ${ }^{15} \mathrm{~N}$ and ${ }^{13} \mathrm{C}$ abundance, aliquots of $1 \mathrm{mg}$ of oven dried and

249 homogenized plant parts were transferred into tin capsules. and introduced into an elemental analyzer (Flash, ThermoFisher, Bremen, Germany) coupled with a Conflo II- Interface

251 (ThermoFisher, Bremen, Germany) to an isotope ratio mass spectrometer (Delta plus ${ }^{\mathrm{XP}}$, 252 ThermoFisher, Bremen, Germany).

253 The amount of ${ }^{15} \mathrm{~N}$ or ${ }^{13} \mathrm{C}$ incorporated as a consequence of labelling into plant parts per gram 254 dry weight (molar excess: ${ }^{n n} X_{\text {in }}\left(\mu \mathrm{mol}\left({ }^{13} \mathrm{C}\right.\right.$ or $\left.\left.{ }^{15} \mathrm{~N}\right) \mathrm{g}^{-1}\right)$ was calculated based on the following 255 equation.

Where ${ }^{n n} X_{t}$ and ${ }^{n n} X_{c}$ are the abundance of ${ }^{15} \mathrm{~N}$ or ${ }^{13} \mathrm{C}$ (atom \%) in labelled and unlabelled control trees, respectively, $[\mathrm{X}]$ is the total $\mathrm{N}$ or $\mathrm{C}$ concentration (\% $\mathrm{N}$ or $\mathrm{C} \mathrm{g}^{-1}$ dry weight), and $\mathrm{MM}$ is the molar mass of ${ }^{15} \mathrm{~N}$ or ${ }^{13} \mathrm{C}\left(\mathrm{g} \mathrm{mol}^{-1}\right)$. The ${ }^{15} \mathrm{~N}$ or ${ }^{13} \mathrm{C}$ incorporated into a particular organ (e.g. leaves) is calculated from ${ }^{n n} X_{i n}$ and the respective organ biomass and summed up over all organs for whole plant uptake. To calculate the relative allocation (i.e. distribution) to different plant organs, the amount of ${ }^{15} \mathrm{~N}$ or ${ }^{13} \mathrm{C}$ incorporated into a given organ (leaves, stem, fine roots, coarse roots) was divided by the whole plant incorporation.

\section{Statistical analysis}

The effect of treatment on various plant physiological processes like photosynthesis, transpiration, stomatal conductance, ${ }^{15} \mathrm{~N}$ assimilation and concentration, and ${ }^{13} \mathrm{C}$ assimilation and concentration, and stress indicators like Leaf water and soil water contents were examined using mixed-model analysis of variance (ANOVA). Separate ANOVAs were conducted for each and species, and Tukey-Kramer, and Sidaks multiple comparison tests were used to isolate specific differences among treatments. Regression models are used to show the correlation between $\mathrm{N}$ uptake, fresh carbon allocation to fine roots, root biomass, and transpiration. A Michaelis-Menten model was fitted iteratively for assessing $V_{\max }$ and $k_{m}$ 
values using Origin 2016 (OriginLab, Northampton, USA) and a one-way ANOVA procedure combined with a Tukey HSD post hoc test was applied to assess treatment effects. Statistical analyses were performed using the statistical program $\mathrm{R}$ version 3.1.2 (R Core Team, 2018) and GraphPad prism software (Prism version 7.00 for Mac OS X, GraphPad Software, La Jolla California USA).

\section{Results}

281 Effects of drought on leaf physiology and growth.

282 The LWP decreased over time in the drought treatments of experiments i) and ii) (Fig. S5) and 283 drought significantly reduced LWP in all species at the end of the drought period (Table 1, 284 Table S3). Similarly, the drought treatments reduced photosynthesis $\left(A_{\text {sat }}\right)$, transpiration $(E)$, and stomatal conductance $\left(g_{s}\right)$ across the different levels of drought for all species (Table 1 ,

286 Figs. S6-8, Tables S4-6). Stem biomass development was assessed using stem height and diameter measurements. Height growth was already completed before the start of the treatments in all species and no further increment was observed during the course of the experiment. In contrast, stem diameter increased during the experiment irrespective of the treatment in all species (Fig. S9). Drought reduced the diameter of $A$. pseudoplatanus, $F$. sylvatica, A. alba and $P$. sylvestris and total biomass in A. pseudoplatanus, F. sylvatica, $Q$. petraea and P. sylvestris (Table 2) compared to well-watered controls. A significant reduction in fine root biomass was observed in saplings of all species under intense drought (Fig. S10).

\section{Effects of drought on combined soil and plant processes affecting plant $N$ uptake.} In experiment i) ${ }^{15} \mathrm{NH}_{4}{ }^{15} \mathrm{NO}_{3}$ was injected into the soil and ${ }^{15} \mathrm{~N}$ uptake and incorporation into the plant biomass was determined to address effects of drought on the complete soil-plant continuum. ${ }^{15} \mathrm{~N}$ incorporation into plant biomass was found significantly reduced as a consequence of drought in all deciduous tree species while this was only a trend for the conifers (Fig. 2 for deciduous, Fig. 3 for conifers, detailed statistics in Table S7). The highest ${ }^{15} \mathrm{~N}$ incorporation in total biomass in the control treatments was observed with $A$. pseudoplatanus and the lowest with $P$. abies (Figs. 2, 3). Severe drought reduced ${ }^{15} \mathrm{~N}$ incorporation in deciduous trees by between 47\% (A. pseudoplatanus) and 79\% (F. sylvatica). 
${ }^{15} \mathrm{~N}$ allocation to different plant compartments. In all species except $Q$. petraea, less of the

$306{ }^{15} \mathrm{~N}$ taken up was allocated to the leaves under extreme drought and instead relatively more

$307{ }^{15} \mathrm{~N}$ remained in the fine roots $(A$. pseudoplatanus, $F$. sylvatica), in the coarse roots $(P$. 308 sylvestris, P. abies) and/or in the stem (A. pseudoplatanus, A. alba) (Figs. 2, 3).

309 Drought also significantly reduced ${ }^{13} \mathrm{C}$ incorporation into plant biomass with the exception of

310 F. sylvatica and severe drought led to reductions of between $70 \%$ (A. pseudoplatanus) and

$31192 \%$ (P. abies) (Fig. 2 for deciduous, Fig. 3 for conifers, detailed statistics in Table S8). In the

312 three deciduous species severe drought and in F. sylvatica also intermediate drought led to a

313 clear reduction of the relative ${ }^{13} \mathrm{C}$ allocation to belowground tissues (Fig. 2). Such pattern was

314 also observed in $A$. alba but $P$. abies showed higher relative ${ }^{13} \mathrm{C}$ allocation to belowground

315 tissues under drought (Fig. 3).

316 Changes in total uptake and in allocation patterns affected ${ }^{15} \mathrm{~N}$ concentrations in leaves

317 (where newly assimilated $\mathrm{N}$ is needed to sustain photosynthesis) and ${ }^{13} \mathrm{C}$ concentrations in

318 roots (where new $\mathrm{C}$ assimilates are needed to support nutrient uptake and assimilation) of

319 the six species (Fig. 4, detailed statistics in Table S9). In F. sylvatica, Q. petraea and A. alba

320 drought significantly reduced ${ }^{15} \mathrm{~N}$ concentrations compared to controls and in $A$.

321 pseudoplatanus, F. sylvatica, and $P$. sylvestris fine root ${ }^{13} \mathrm{C}$ concentrations were reduced.

322 In order to examine if the changes in $\mathrm{C}$ allocation under drought affected $\mathrm{N}$ uptake, we 323 assessed the linkage between the total ${ }^{15} \mathrm{~N}$ taken up by the plants and parameters 324 representing changes in ${ }^{13} \mathrm{C}$ allocation to the fine roots (Fig. 5, Table S10). There was a 325 significant correlation $\left(R^{2}=0.76, p=<0.0001\right)$ between the ${ }^{15} \mathrm{~N}$ incorporated into whole plant 326 biomass and the total amount of ${ }^{13} \mathrm{C}$ transported to the fine root across all species and 327 drought treatments (Fig. 5a). Comparable relationships were observed when the relative 328 amount of ${ }^{13} \mathrm{C}$ allocated to the roots $\left(R^{2}=0.77, p=<0.0001\right.$; Fig. $\left.5 b\right)$ or the ${ }^{13} \mathrm{C}$ concentration 329 in the fine roots $\left(R^{2}=0.76, p=<0.0001\right.$; Fig $\left.5 c\right)$ were considered. There was also a similar 330 relationship between total ${ }^{15} \mathrm{~N}$ incorporation and fine root biomass across all treatments $\left(R^{2}\right.$ $331=0.75, p=<0.0001$, Fig. 6 , Table S11) indicating that not only short but also longer-term C 332 allocation belowground affects $\mathrm{N}$ uptake. Total $\mathrm{N}$ uptake per $\mathrm{g}$ root biomass was comparable 333 between control and moderate drought (over all species: $102 \pm 66 \mu \mathrm{mol}{ }^{15} \mathrm{~N} \mathrm{~g}^{-1}$ root dry 334 weight and $102 \pm 65 \mu \mathrm{mol}^{15} \mathrm{~N} \mathrm{~g}^{-1}$, respectively) and slightly lower $\left(78 \pm 54 \mu \mathrm{mol}{ }^{15} \mathrm{~N} \mathrm{~g}^{-1}\right)$ for 335 the severe drought treatment. The potential effects of drought induced changes in 336 transpiration on $\mathrm{N}$ uptake is shown in Fig. $5 \mathrm{~d}$. A low positive linear correlation between ${ }^{15} \mathrm{~N}$ 
incorporated into plant biomass and leaf level transpiration $\left(R^{2}=0.30, p=<0.0181\right)$ was

338 observed.

340 Effects of drought and C transport on nitrate and ammonium uptake systems.

341 In experiment ii) concentration dependent root net uptake capacities as affected by drought were assessed. In contrast to total plant incorporation of ${ }^{15} \mathrm{~N}$ from the soil as assessed in experiment i) deciduous trees were not significantly affected in their concentration

344 dependent nitrate or ammonium uptake rates by drought (Fig. 7). Even though ${ }^{15} \mathrm{~N}$

345 incorporation from the soil (i.e. in experiment i) was not affected in conifers, severe drought

346 reduced maximum ammonium but not nitrate uptake rates $\left(V_{\max }\right)$ in $A$. alba and $P$. abies (Fig.

347 8). $K_{m}$ values for nitrate and ammonium uptake were not affected by drought for neither of

348 the species (Fig. 7 for deciduous trees, Fig. 8 for conifers).

349 To independently test if reduced $C$ allocation to the roots does or does not affect the root

350 nitrate uptake systems, we applied a girdling treatment in two tree species in experiment iii).

351 Girdling did not affect LWP of $F$. sylvatica throughout the course of experiment but caused a 352 significant decrease in LWP for $P$. sylvestris towards the end of the experiment (Table.1, Fig.

353 S11, Table S12). In addition, gas exchange measurement data showed that girdling resulted 354 in a significant reduction in $A, E$, and $g_{s}$ in both F. sylvatica and $P$. sylvestris (Table 1, Figs S1235513 , Tables S13-15). Similarly, girdling reduced ${ }^{13} \mathrm{C}$ uptake by $60.6 \%(p=0.5901)$ and $41.1 \%$ ( $p$ $356=0.0032$ ) in F. sylvatica and P. sylvestris, respectively (Fig. 9b, Table S16). Moreover, relative 357 to total ${ }^{13} \mathrm{C}$ uptake, significantly lower proportions of ${ }^{13} \mathrm{C}$ where allocated belowground $(F$. 358 sylvatica: Control: $35.5 \pm 18.0 \%$, Girdling: $18.4 \pm 13.7 \% ; p=0.0004 ;$ P. sylvestris: Control 9.8 $359 \pm 8.7 \%$, Girdling: $1.5 \pm 1.4 \% ; p=0.12$; Table S17). This reduction in the transport of newly 360 assimilated $\mathrm{C}$ belowground did, however, not significantly affect nitrate uptake capacity from 361 nutrient solutions (Fig. 9a, Table S17).

\section{Discussion}

$364 \mathrm{~N}$ absorption by trees from the soil mainly depends on three factors: a) Nutrient availability 365 at the root surface, b) the absorbing root surface area and c) the efficiency of the plant uptake 366 and assimilation systems, and all these factors might be severely affected by drought 367 (Kreuzwieser and Gessler, 2010). 
With our approaches we were able to distinguish c) from the other factors. Still we need to acknowledge that our study did not account for drought effects on mycorrhizal associations and rhizosphere microorganisms in general, which play an important role in the drought response of plants (e.g., Santander et al., 2017). Moreover, we assessed saplings and the responses of adult trees might be different as they e.g., have larger $C$ storage pools to buffer the reduced $\mathrm{C}$ availability under drought. Finally, we only addressed inorganic $\mathrm{N}$ uptake even though it is known that the uptake of organic $\mathrm{N}$ can be important in forest trees and ecosystems (Näsholm et al., 2009).

Total inorganic $N$ uptake from the soil under drought is impaired by reduced root biomass and lower belowground assimilate allocation In experiment i), we aimed at assessing the combined effect of soil and plant processes on $\mathrm{N}$ uptake. We observed a significant reduction of $\mathrm{N}$ uptake under severe drought stress for the three deciduous species and a comparable (though not significant) trend for the conifers. In experiment ii) we observed that ammonium and nitrate transporter characteristics were not significantly influenced in deciduous species by drought but that $\mathrm{V}_{\max }$ for ammonium uptake was reduced in $A$. alba and P. abies. On the one hand, any drought effect on whole plant $\mathrm{N}$ uptake from the soil as observed in the deciduous species must thus be attributed to root nutrient availability and/or root biomass or surface area. On the other hand, the reduced $V_{\max }$ ammonium in the two-conifer species did not lead to effects on whole plant $\mathrm{N}$ uptake. A reduction in soil nutrient availability during drought may occur for several reasons, including lower microbial nutrient mineralization, and altered plant - microbe interactions (Fierer and Schimel, 2002; Hawkins and Crawford, 2018). As we added similar amounts of ${ }^{15} \mathrm{~N}$ labelled ammonium nitrate to the soil in the different treatment we did not account for such re-supply effects. Reduced soil water content can cause lower diffusion through the soil matrix and also lower nutrient transport by water mass flow influenced by plant transpiration to the root surface (Schoonover and Crim, 2015). As the same soil was used, and water content was similar in the drought treatments across species the differences between deciduous and coniferous species in terms of drought impact on $\mathrm{N}$ uptake might not be primarily related to diffusion. In addition, $\mathrm{N}$ uptake might also be influenced by changes in root hydraulic conductivity and drought stress is considered to cause a reduction in root hydraulic conductivity due to increased suberization of roots (Steudle, 2000). The positive (though not 
very strong) relationship between transpiration and whole plant $\mathrm{N}$ uptake, therefore, points to an effect of water mass flow in the soil-plant-atmosphere continuum.

402 In our drought experiments with saplings, extreme drought reduced fine root biomass (and 403 thus active surface area for nutrient uptake), and in 5 out of 6 species also the amount of 404 newly assimilated ${ }^{13} \mathrm{C}$ carbon. These results of the ${ }^{13} \mathrm{C}$ pulse labelling approach agree with the assessments of assimilation on the leaf level. Drought not only impaired C assimilation but also reduced allocation of new assimilates to roots in most of the species tested. Reduced allocation to roots might be a result of increasing phloem sap viscosity under drought that leads to reduced sieve-tube conductivity (Dannoura et al. 2019). It has already been shown that fine root biomass is crucial for tree- and stand-based nutrient uptake under drought as is the exploitation of the soil volume by root foraging (de Kroon and Mommer, 2006) to compensate for the reduction of the mobility of ions under water restriction. Our results are in agreement with previous findings showing that severe drought can strongly impede root growth (Eghball and Maranville, 1993). However, in contrast to our hypothesis 2 we could neither observe a stimulation of root growth nor of allocation of new assimilates belowground (cf., Leuschner et al., 2001; Hommel et al. 2016) with moderate drought. Such differences to previous publications might be due to differences in drought intensity, duration of the drought events and species-specific differences. Over all treatments,

418 fine root biomass significantly influenced $\mathrm{N}$ uptake, associating $75 \%$ of variation in $\mathrm{N}$ uptake

419 to root biomass, and a comparably high relationship was observed with allocation of new 420 assimilates belowground.

421 We conclude that drought mainly negatively affected $\mathrm{C}$ allocation to root biomass and that 422 the lower fine root biomass growth reduced the nutrient foraging capacity. Reduced 423 allocation of new assimilates belowground during drought is known to also reduce the 424 exudation of carbon to the rhizosphere and the supply of rhizo-dependent soil microbes (e.g., 425 Rein et al., 2016). Dannenmann et al., (2009) showed that such a reduction of belowground 426 C allocation and exudation might lead to a shift in the abilities between roots of adult trees 427 and free-living microbes to compete for $\mathrm{N}$. The authors observed an increase in nitrate uptake 428 by roots of beech trees and at the same time a reduction of microbial biomass and $\mathrm{N}$ 429 immobilisation and argued that trees might be able to "starve-out" the micro-organisms. Such 430 an effect was, however, not observed with beech saplings (Winkler et al., 2010) being in 431 agreement with our findings for six different coniferous and deciduous species. Simon et al., 
432 (2017) argued that the amount of $C$ transferred to the soil via exudation by saplings is

433 generally too low to introduce a visible change in microbial activity on an ecosystem scale.

435 Ammonium uptake capacity is reduced by drought in two coniferous species, but such

436 physiological impairment does not significantly restrict total inorganic $N$ uptake

437 Our data demonstrated that root uptake capacity for inorganic $\mathrm{N}$ forms was not affected in 438 deciduous saplings by drought events, even though total in situ $\mathrm{N}$ uptake was reduced 439 significantly in the three deciduous species. In contrast while $V_{\max }$ for ammonium was reduced

440 in $A$. alba and $P$. abies under severe drought their total $N$ uptake from the soil was not 441 significantly reduced. The reduction of the ammonium uptake capacity in the conifer species 442 is in contrast to findings with Populus simmonii saplings (Zhang et al. 2018) and Malus 443 prunifolia (Huang et al., 2018) seedlings. The further authors observed an increase in 444 ammonium transporter transcript abundance and ammonium uptake and the latter an 445 increase in ammonium at the expense of nitrate uptake. In coffee trees, $V_{\max }$ and $K_{m}$ for 446 nitrate uptake were significantly reduced upon drought stress (Martinez et al. 2020). These 447 differences might be due to species-specific responses and due to different drought 448 intensities applied.

449 The ability of tree roots to absorb $\mathrm{N}$ available at the root surface depends upon the 450 characteristics of the $\mathrm{N}$ transporters (i.e. their abundance and their activity) involved in the 451 active transport across the cell membrane. The capability of a plant root to efficiently take up 452 the nutrients available in the rhizosphere are defined by the kinetic characteristics of the 453 nutrient transporters (i.e. transporter affinity and maximum uptake capacity) (Glass et al., 454 1992). As root $\mathrm{N}$ uptake and assimilation are important energy demanding processes in roots 455 (Pfautsch et al., 2009), and a large proportion of energy demanding processes in the roots 456 depend on the belowground transport of new assimilates (Högberg et al. 2001), we 457 hypothesised that the amount of recently assimilated carbon transported to the fine roots 458 would modify the nitrate and ammonium uptake capacity. It is without doubt that sugars play 459 a central role in the regulation of $\mathrm{N}$ uptake and assimilation (Gessler et al., 2004) supported 460 by observations, that a decrease in nitrate uptake at night was reversed by feeding sucrose 461 to the roots, which affected nitrate transporters on the transcriptional level (Lejay et al., 462 1999). The close coupling between $\mathrm{N}$ and $\mathrm{C}$ metabolism can also be explained by the demand 463 for $\mathrm{C}$ skeletons during $\mathrm{N}$ assimilation; indeed up to $55 \%$ of the assimilated $\mathrm{C}$ can be committed 
464 to $\mathrm{N}$ assimilation and metabolism (Huppe and Turpin, 1994). The findings that root uptake 465 capacity remained unaltered during the drought period in four of six species and was in these

466 species not affected by drought-induced reduction of $\mathrm{C}$ transport to the roots lead us, 467 however, to reject our initial hypothesis. This conclusion is also supported by the findings of 468 experiment $i$ ) that mainly the drought-induced reduction of root biomass is a factor for the 469 reduction of total plant $\mathrm{N}$ uptake. Our results from the drought treatment, were corroborated 470 by the girdling experiment that effectively prevented allocation of recent assimilates 471 belowground and did not influence the root $\mathrm{N}$ uptake capacity in beech and pine.

472 We conclude that the reduction of the allocation of newly assimilated carbon to the fine roots 473 during short term drought periods did not induced a general energy or C-skeleton limitation 474 for the active uptake of $\mathrm{N}$ by fine roots. One mechanism that could compensate the reduction 475 of allocation of new assimilates to fine roots is the remobilisation of stored carbon. Galiano 476 et al., (2017) showed that 10 weeks of drought, did not deplete but rather increase the starch 477 and sugar pools in P. sylvestris and Tilia platyphyllos and at the same time root biomass 478 decreased during drought. Lower fine root biomass and thus reduced nutrient absorbing area 479 thus can come with an increase in sugar and starch concentration. We might thus conclude 480 that specific uptake rates (per g root biomass) were not affected by drought in the three 481 deciduous species and in P. sylvestris as sufficient carbohydrates (per g root biomass) were 482 still available despite reduced $\mathrm{C}$ allocation. We might speculate that the carbohydrate 483 reserves were lower in the two species ( $A$. alba, P. abies) with the drought induced reduction 484 of ammonium uptake. However, nitrate uptake capacity was not affected in these species 485 even though additional energy is needed for reducing nitrate before being incorporated into 486 amino acids. The reduction in ammonium uptake capacity in response to drought in the 487 conifers did not affect total $\mathrm{N}$ extraction from the soil; rather the opposite was the case as 488 the deciduous tree species (even though their uptake kinetics was not affected) and not the 489 conifers showed a significant reduction of $\mathrm{N}$ uptake in experiment i). We need to conclude 490 that the reduced ammonium uptake capacity was not restricting total $\mathrm{N}$ uptake in the soil in $491 \quad$ A. alba and P. abies.

492

493 Conclusion 
494 Currently, the interaction between carbon starvation and hydraulic failure is in the focus of

495 the scientific debates concerning the effects of drought on the functioning of trees. It is 496 important to address the fact that drought might also impair the functioning of trees via 497 restrictions in the nutrient supply but a clear mechanistic basis that allows to inform 498 biogeochemical models is lacking. By linking $\mathrm{N}$ uptake with the carbon and water balance, our 499 study shows that drought events resulted in a) reduction of actual soil nutrient uptake mainly 500 in deciduous trees accompanied by b) reduced carbon allocation to the roots and c) reduction 501 in root biomass and thus surface area available for $\mathrm{N}$ uptake. Reduced $\mathrm{C}$ allocation 502 belowground did not generally impose any energy or carbon restriction on the functioning of 503 the root $\mathrm{N}$ uptake system during short drought periods and several species might compensate 504 a lack of new assimilates by using storage reserves. On the longer term this compensation 505 might not be possible any longer; however, Aaltonen et al. (2017), observed that prolonged drought stress of 15 months led to acclimation and even an increase in $\mathrm{N}$ uptake.

\section{Conflict of Interest}

$510 \quad$ None declared

\section{Funding}

513 Swiss National Science Foundation SNF (31003A_159866).

\section{Acknowledgements}

516 We thank Matthias Saurer and Manuela Oettli for helping us by analysing the samples. We

517 also thank Andri Gustin, and Johannes Frey for helping in preparing the samples.

\section{Author Contribution}

520 A.G., and J.J. designed the experiment. L.B., K.S., N.B., JL., and J.J collected the samples. J.J. 521 analysed the data. J.J., and A.B. performed the statistics. J.J. and A.G. wrote the manuscript. 522 L.B., K.S., N.B., A.B., J.L. commented on and edited the manuscript. 


\section{References}

524 Aaltonen, H., Lindén, A., Heinonsalo, J., Biasi, C., Pumpanen, J, 2016. Effects of prolonged drought stress on 525 Scots pine seedling carbon allocation. Tree Physiol. 37, 418-427.

526 Allen, C.D., Macalady, A.K., Chenchouni, H., Bachelet, D., McDowell, N., Vennetier, M., Kitzberger, T., Rigling, A., Breshears, D.D., Hogg, E.H. (Ted), Gonzalez, P., Fensham, R., Zhang, Z., Castro, J., Demidova, N., Lim, J.-H., Allard, G., Running, S.W., Semerci, A., Cobb, N., 2010. A global overview of drought and heatinduced tree mortality reveals emerging climate change risks for forests. For. Ecol. Manage. 259, 660684. https://doi.org/10.1016/J.FORECO.2009.09.001

Anderegg, W.R.L., Martinez-Vilalta, J., Cailleret, M., Camarero, J.J., Ewers, B.E., Galbraith, D., Gessler, A., Grote, R., Huang, C., Levick, S.R., Powell, T.L., Rowland, L., Sánchez-Salguero, R., Trotsiuk, V., 2016. When a Tree Dies in the Forest: Scaling Climate-Driven Tree Mortality to Ecosystem Water and Carbon Fluxes. Ecosystems 19, 1133-1147. https://doi.org/10.1007/s10021-016-9982-1

Bouriaud, O., Popa, I., 2009. Comparative dendroclimatic study of Scots pine, Norway spruce, and silver fir in the Vrancea Range, Eastern Carpathian Mountains. Trees 23, 95-106.

Breshears, D.D., Allen, C.D., 2002. The importance of rapid, disturbance-induced losses in carbon management and sequestration. Glob. Ecol. Biogeogr. 11, 1-5. https://doi.org/10.1046/j.1466-822X.2002.00274.x

Ciais, P., Reichstein, M., Viovy, N., Granier, A., Ogée, J., Allard, V., Aubinet, M., Buchmann, N., Bernhofer, C.,

Dannenmann, M., Simon, J., Gasche, R., Holst, J., Naumann, P.S., Kögel-Knabner, I., Knicker, H., Mayer, H., Keronen, P., Knohl, A., Krinner, G., Loustau, D., Manca, G., Matteucci, G., Miglietta, F., Ourcival, J.M., Papale, D., Pilegaard, K., Rambal, S., Seufert, G., Soussana, J.F., Sanz, M.J., Schulze, E.D., Vesala, T., Valentini, R., 2005. Europe-wide reduction in primary productivity caused by the heat and drought in 
de Kroon, H., Mommer, L., 2006. Root foraging theory put to the test. Trends Ecol. Evol. 21, 113-116.

$$
\text { https://doi.org/10.1016/j.tree.2005.11.021 }
$$

Dion, P.-P., Jämtgård, S., Bertrand, A., Pepin, S., Dorais, M., 2018. Organic Nitrogen Uptake and Assimilation in Cucumis sativus Using Position-Specific Labeling and Compound-Specific Isotope Analysis. Front. Plant Sci. 9, 1596. https://doi.org/10.3389/fpls.2018.01596

Eghball, B., Maranville, J.W., 1993. Root Development and Nitrogen Influx of Corn Genotypes Grown under Combined Drought and Nitrogen Stresses. Agron. J. 85, 147. https://doi.org/10.2134/agronj1993.00021962008500010027x

Farrick, K.K., Wuddivira, M.N., Martin, O., 2019. Estimation of soil texture from permanent wilting point measured with a chilled-mirror dewpoint technique. J. Plant Nutr. Soil Sci. 182, 119-125. https://doi.org/10.1002/jpln.201700573

Fierer, N., Schimel, J.P., 2002. Effects of drying-rewetting frequency on soil carbon and nitrogen transformations. Soil Biol. Biochem. 34, 777-787. https://doi.org/10.1016/S0038-0717(02)00007-X

Fotelli, M.N., Rennenberg, H., Gessler, A., 2002. Effects of Drought on the Competitive Interference of an Early

Fotelli, M., Rienks, M., Rennenberg, H., Gessler, A., 2004. Climate and forest management affect ${ }^{15} \mathrm{~N}$-uptake, N balance and biomass of European beech seedlings. Trees 18, 157-166. Rennenberg, H., 2005. Climate and forest management influence nitrogen balance of European beech between nitrogen compounds, cytokinins and carbon metabolism. Tree Physiol. 24, 1313-21. 
Gessler, A., Kreuzwieser, J., Dopatka, T., Rennenberg, H., 2002. Diurnal courses of ammonium net uptake by the roots of adult beech (Fagus sylvatica) and spruce (Picea abies) trees. Plant Soil 240, 23-32. https://doi.org/10.1023/A:1015831304911

Gessler, A., Schaub, M., McDowell, N.G., 2017. The role of nutrients in drought-induced tree mortality and recovery. New Phytol. 214, 513-520. https://doi.org/10.1111/nph.14340

Gessler, A., Schneider, S., Von Sengbusch, D., Weber, P., Hanemann, U., Huber, C., Rothe, A., Kreutzer, K., Rennenberg, H., 1998. Field and laboratory experiments on net uptake of nitrate and ammonium by the roots of spruce (Picea abies) and beech (Fagus sylvatica) trees. New Phytol. 138, 275-285. https://doi.org/10.1046/j.1469-8137.1998.00107.x

Ghashghaie, J., Saugier, B., 1989. Effects of nitrogen deficiency on leaf photosynthetic response of tall fescue to water deficit. Plant, Cell Environ. 12, 261-271. https://doi.org/10.1111/j.1365-3040.1989.tb01940.x

Glass, A.D., Shaff, J.E., Kochian, L. V, 1992. Studies of the Uptake of Nitrate in Barley : IV. Electrophysiology. Plant Physiol. 99, 456-63.

Gockele, A., Weigelt, A., Gessler, A., Scherer-Lorenzen, M., 2014. Quantifying resource use complementarity in grassland species: A comparison of different nutrient tracers. Pedobiologia. 57, 251-256. https://doi.org/10.1016/j.pedobi.2014.09.001

Graf Pannatier, E., Dobbertin, M., Heim, A., Schmitt, M., Thimonier, A., Waldner, P., Frey, B., 2012. Response of carbon fluxes to the 2003 heat wave and drought in three mature forests in Switzerland. Biogeochemistry 107, 295-317. https://doi.org/10.1007/s10533-010-9554-y

Hagedorn, F., Joseph, J., Peter, M., Luster, J., Pritsch, K., Geppert, U., Kerner, R., Molinier, V., Egli, S., Schaub, M., Liu, J.-F., Li, M., Sever, K., Weiler, M., Siegwolf, R.T.W., Gessler, A., Arend, M., 2016. Recovery of trees from drought depends on belowground sink control. Nat. Plants 2, 16111. https://doi.org/10.1038/nplants.2016.111

Hawkins, A., Crawford, K., 2018. Interactions between plants and Soil Microbes may alter the Relative Importance of Intraspecific and Interspecific Plant Competition in a Changing Climate. AoB Plants 10. https://doi.org/10.1093/aobpla/ply039

Hommel, R., Siegwolf, R., Zavadlav, S., Arend, M., Schaub, M., Galiano, L., Haeni, M., Kayler, Z.E., Gessler, A., Adams, W., 2016. Impact of interspecific competition and drought on the allocation of new assimilates in trees. Plant Biol. 18, 785-796. https://doi.org/10.1111/plb.12461 

leaves depends on species, provenance, climate conditions and soil type. Plant Biol. 15, 198-209.

$611 \quad$ https://doi.org/10.1111/j.1438-8677.2012.00658.x

612 Huang, L., Li, M., Zhou, K., Sun, T., Hu, L., Li, C., Ma, F., 2018. Uptake and metabolism of ammonium and nitrate 613 in response to drought stress in Malus prunifolia. Plant Physiol Biochem. 127, 185-193.

614 Huppe, H.C., Turpin, D.H., 1994. Integration of Carbon and Nitrogen Metabolism in Plant and Algal Cells. Annu. Rev. Plant Physiol. Plant Mol. Biol. 45, 577-607. https://doi.org/10.1146/annurev.pp.45.060194.003045

Kirste, B., Durner, W., 2018. Determining the soil water retention curve across the whole moisture range by combining HYPROP and WP4C data. Geophys. Res. Abstr. 20, 2018-18257.

Kreuzwieser, J., Gessler, A., 2010. Global climate change and tree nutrition: influence of water availability. Tree Physiol. 30, 1221-1234. https://doi.org/10.1093/treephys/tpq055 https://doi.org/10.1016/j.foreco.2005.08.015 functional regulation of two NO3- uptake systems by N- and C-status of Arabidopsis plants. Plant J. 18, 509-19. at leaf, stem and fine root levels of competitive Fagus sylvatica L. and Quercus petraea (Matt.) Liebl.

Liu, M., Li, C., Xu, X., Wanek, W., Jiang, N., Wang, H., Yang, X., 2017. Organic and inorganic nitrogen uptake by trees in dry and wet years. For. Ecol. Manage. 149, 33-46. https://doi.org/10.1016/S0378-

Lukac, M., Calfapietra, C., Lagomarsino, A., Loreto, F., 2010. Global climate change and tree nutrition: effects of elevated $\mathrm{CO}_{2}$ and temperature. Tree Physiol. 30, 1209-1220. https://doi.org/10.1093/treephys/tpq040 New Jersey. 

Horticulturae 267, 109254.

Mcdowell, N., Pockman, W.T., Allen, C.D., Breshears, D.D., Cobb, N., Kolb, T., Plaut, J., Sperry, J., West, A., Williams, D.G., Yepez, E.A., Mcdowell, N., Pockman, W.T., Allen, C.D., David, D., Mcdowell, N., Cobb, N., Kolb, T., Plaut, J., Sperry, J., 2008. Mechanisms of Plant Survival and Mortality during Drought : Why Do Some Plants Survive while Others Succumb to Drought ? New Phytol. 178, 719-739

McDowell, N.G., 2011. Mechanisms linking drought, hydraulics, carbon metabolism, and vegetation mortality. Plant Physiol. 155, 1051-9. https://doi.org/10.1104/pp.110.170704

Millard, P., Grelet, G. -a., 2010. Nitrogen storage and remobilization by trees: ecophysiological relevance in a changing world. Tree Physiol. 30, 1083-1095. https://doi.org/10.1093/treephys/tpq042

Millard, P., Proe, M.F., 1992. Storage and internal cycling of nitrogen in relation to seasonal growth of Sitka spruce. Tree Physiol. 10, 33-43.

Näsholm, T., Kielland, K., Ganeteg, U., 2009. Uptake of organic nitrogen by plants. New Phytol. 182, 31-48.

Pfautsch, S., Rennenberg, H., Bell, T.L., Adams, M.A., 2009. Nitrogen uptake by Eucalyptus regnans and Acacia spp. - preferences, resource overlap and energetic costs. Tree Physiol. 29, 389-399. https://doi.org/10.1093/treephys/tpn033

Reich, P.B., Hobbie, S.E., Lee, T., Ellsworth, D.S., West, J.B., Tilman, D., Knops, J.M.H., Naeem, S., Trost, J., 2006. Nitrogen limitation constrains sustainability of ecosystem response to CO2. Nature 440, 922-925. https://doi.org/10.1038/nature04486

Rein, I. von, Gessler, A., Premke, K., Keitel, C., Ulrich, A., Kayler, Z.E., 2016. Forest understory plant and soil microbial response to an experimentally induced drought and heat-pulse event: the importance of maintaining the continuum. Glob. Chang. Biol. 22, 2861-2874. https://doi.org/10.1111/GCB.13270 being resolved. New Phytol. 186, 274-281. https://doi.org/10.1111/j.1469-8137.2009.03167.x mycorrhiza effects on plant performance under osmotic stress. Mycorrhiza 27: 639-657. thermal imaging of forest canopies. Agr. Forest. Meteor. 151, 1632-1640. 
Sevanto, S., McDowell, N.G., Dickman, L.T., Pangle, R., T., P.W., 2014. How do trees die? A test of the hydraulic failure and carbon starvation hypotheses. Plant. Cell Environ. 37, 153-161. https://doi.org/10.1111/pce.12141

Simon, J., Dannenmann, M., Pena, R., Gessler, A., Rennenberg, H., 2017. Nitrogen nutrition of beech forests in a changing climate: importance of plant-soil-microbe water, carbon, and nitrogen interactions. Plant Soil 418, 89-114. https://doi.org/10.1007/s11104-017-3293-y

Steudle, E., 2000. Water uptake by plant roots: an integration of views, Plant and Soil. 226,45-56.

Sun, J., Ye, M., Peng, S., Li, Y., 2016. Nitrogen can improve the rapid response of photosynthesis to changing irradiance in rice (Oryza sativa L.) plants. Sci. Rep. 6, 31305. https://doi.org/10.1038/srep31305

Sun, X., Wen, X., Yu, G., Liu, Y., Liu, Q., 2006. Seasonal drought effects on carbon sequestration of a midsubtropical planted forest of southeastern China. Sci. China Ser. D Earth Sci. 49, 110-118. https://doi.org/10.1007/s11430-006-8310-6

Unger, S., Máguas, C., Pereira, J.S., David, T.S., Werner, C., 2010. The influence of precipitation pulses on soil respiration - Assessing the "Birch effect" by stable carbon isotopes. Soil Biol. Biochem. 42, 1800-1810. https://doi.org/10.1016/J.SOILBIO.2010.06.019

Winkler, J.B., Dannenmann, M., Simon, J., Pena, R., Offermann, C., Sternad, W., Clemenz, C., Naumann, P.S., Gasche, R., Kögel-Knabner, I., Gessler, A., Rennenberg, H., Polle, A., 2010. Carbon and nitrogen balance in beech roots under competitive pressure of soil-borne microorganisms induced by girdling, drought and glucose application. Funct. Plant Biol. 37, 879. https://doi.org/10.1071/FP09309 
695 Figure 1: Scheme of the experimental designs of experiment i)-iii). In experiments i) and ii)

6966 tree species were subjected to 5 weeks of drought treatments (moderate drought, severe drought, control). In experiment i) ${ }^{15} \mathrm{NH}_{4}{ }^{15} \mathrm{NO}_{3}$ was applied to the soil 3 weeks after the start of the drought and 5 days later ${ }^{13} \mathrm{CO}_{2}$ labelling was applied. At the end of the experiments, the plants were harvested and ${ }^{13} \mathrm{C}$ and ${ }^{15} \mathrm{~N}$ incorporation was assessed in the different plant organs. In experiment ii) nitrate and ammonium uptake kinetics were determined with excavated roots after 5 weeks of treatment. In experiment iii) plants were subjected to girdling (vs. ungirdled controls) for 5 weeks. 25 days after the onset of the treatment plants were labelled with ${ }^{13} \mathrm{CO}_{2}$. At the end of the treatment nitrate uptake was assessed with excavated roots and plants were harvested to assess label incorporation.

Figure 2: ${ }^{15} \mathrm{~N}$, and ${ }^{13} \mathrm{C}$ distribution across different plant organs in broad leaf species in response to drought in experiment $\mathrm{i}$ ). The figure shows the relative distribution of the ${ }^{15} \mathrm{~N}$ and ${ }^{13} \mathrm{C}$ incorporated in total plant biomass as a consequence of labelling to the different plant organs in Acer pseudoplatanus (a, b), Fagus sylvatica (c, d) and Quercus petraea (e, f), respectively. On top of each column the absolute amount of ${ }^{15} \mathrm{~N}\left(\mu \mathrm{mol}{ }^{15} \mathrm{~N} \pm \mathrm{SD}\right.$ ) and ${ }^{13} \mathrm{C}$ ( $\mu \mathrm{mol}^{13} \mathrm{C} \pm \mathrm{SD}$ ) incorporated in the total plant biomass as a consequence of labelling is given. (Signif. codes: ${ }^{* * * *}: \mathrm{p}<0.0001,{ }^{* *}: \mathrm{p}<0.001,{ }^{* *}: \mathrm{p}<0.01, *: \mathrm{p}<0.05$ ).

Figure 5: Correlation between ${ }^{15} \mathrm{~N}$ incorporated in total plant biomass and ${ }^{13} \mathrm{C}$ in fine root incorporated in total fine root biomass, b) ${ }^{15} \mathrm{~N}$ incorporated in total plant biomass and

Figure $3:{ }^{15} \mathrm{~N}$, and ${ }^{13} \mathrm{C}$ distribution across different plant organs in conifers in response to drought in experiment i). The figure shows the relative distribution of the ${ }^{15} \mathrm{~N}$ and ${ }^{13} \mathrm{C}$ incorporated in total plant biomass as a consequence of labelling to the different plant organs in Picea abies ( $a, b)$, Abies alba (c, d) and Pinus sylvestris $(e, f)$, respectively. On top of each column the absolute amount of ${ }^{15} \mathrm{~N}\left(\mu \mathrm{mol}{ }^{15} \mathrm{~N} \pm \mathrm{SD}\right)$ and ${ }^{13} \mathrm{C}\left(\mu \mathrm{mol}{ }^{13} \mathrm{C} \pm \mathrm{SD}\right)$ incorporated in the total plant biomass as a consequence of labelling is given. (Signif. codes: ${ }^{* * *}: p<0.001$, $*: p<0.05)$.

Figure $4:{ }^{15} \mathrm{~N}$ and ${ }^{13} \mathrm{C}$ concentration in leaf and fine root biomass in response to drought. ${ }^{15} \mathrm{~N}$ concentration in leaf biomass and ${ }^{13} \mathrm{C}$ concentration in fine root biomass for deciduous $(\mathrm{a}, \mathrm{c})$ and coniferous $(b, d)$ tree species. Concentrations are based in dry weight (dw). Signif. codes: $* *: p<0.01, *: p<0.05$. percentage of ${ }^{13} \mathrm{C}$ allocation to fine root biomass, c) ${ }^{15} \mathrm{~N}$ incorporated in total plant biomass and to concentration of ${ }^{13} \mathrm{C}$ per gram of fine root biomass, and $\left.\mathrm{d}\right){ }^{15} \mathrm{~N}$ incorporated in total plant biomass versus transpiration measured the day before harvesting. All data shown are based on dry biomass. Each data points shows mean with standard deviation for one tree species.

Figure 6: Correlation between ${ }^{15} \mathrm{~N}$ incorporated into total plant biomass in relation to total fine root dry biomass. Black dashed lines denote linear regression, dashed red lines shows 
738

739

740

741

742

743

744

745

746

747

748

749

750

751

752

753

754

755

756

757

758

759
95\% confidence interval. Each data points shows mean with standard deviation for one tree species.

Figure 7: Net nitrogen uptake kinetics in broadleaf species. Concentration dependent ammonium $(a, c, e)$ and nitrate $(b, d, f)$ net uptake kinetics of root tips $(n=3)$ in experiment ii). $a, b)$ shows the ${ }^{15} \mathrm{~N}$ uptake kinetics of Acer pseudoplatanus, c, d) represents Fagus sylvatica, $e, f)$ denotes Quercus petraea. Letters $a, b$ indicates significant differences $(p<0.5)$ of $V_{\max }$ or $\mathrm{k}_{\mathrm{m}}$ between drought treatments. Uptake rates are based on root fresh weight.

Figure 8: Net nitrogen uptake kinetics in conifers. Concentration dependent ammonium (a, $c, e)$ and nitrate ( $b, d, f)$ net uptake kinetics of root tips $(n=3)$ in experiment $i i)$. $a, b)$ shows the ${ }^{15} \mathrm{~N}$ uptake kinetics of Abies alba, c, d) represents Picea abies, e, f) denotes Pinus sylvestris. Letters $a, b$ indicates significant differences $(p<0.5)$ of $V_{\max }$ or $k_{m}$ between drought treatments. Uptake rates are based on root fresh weight

Figure 9: ${ }^{15} \mathrm{~N}$ in fine root biomass and ${ }^{13} \mathrm{C}$ in total plant biomass in response to girdling. ${ }^{15} \mathrm{~N}$ concentration in fine root dry biomass (a), and ${ }^{13} \mathrm{C}$ total incorporated in total plant dry biomass (b) after the girdling in experiment iii). 
Experiment i) and ii): 5 weeks of treatment: control, moderate, severe drought

A. pseudoplatanus, F. sylvatica, Q. petraea, P. abies, A. alba, P. sylvestris

Assessment of

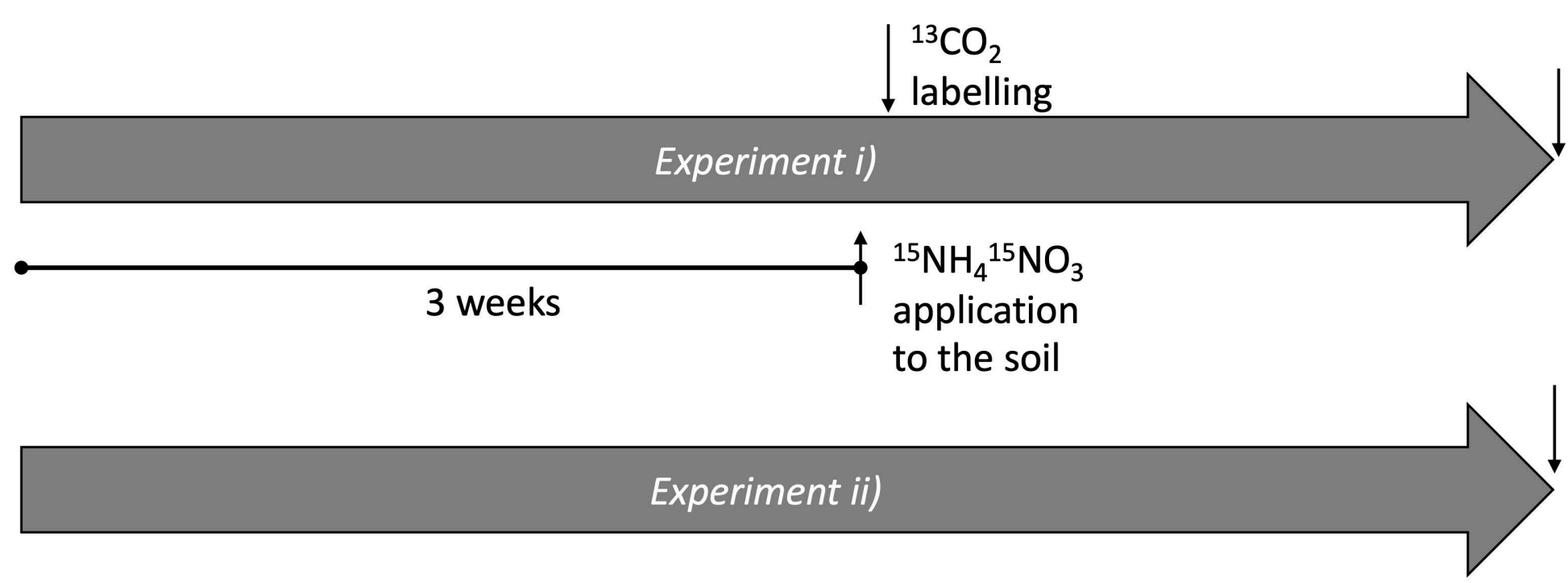
whole plant ${ }^{15} \mathrm{~N}$ and ${ }^{13} \mathrm{C}$ uptake and allocation Plant harvest

Assessment of nitrate and ammonium uptake kinetics

Experiment ii): 5 weeks of treatment: control, girdling

F. sylvatica, P. sylvestris

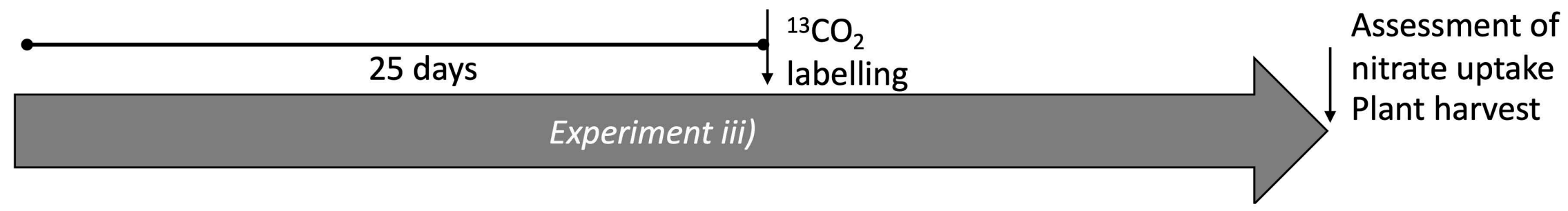


A. pseudoplatanus
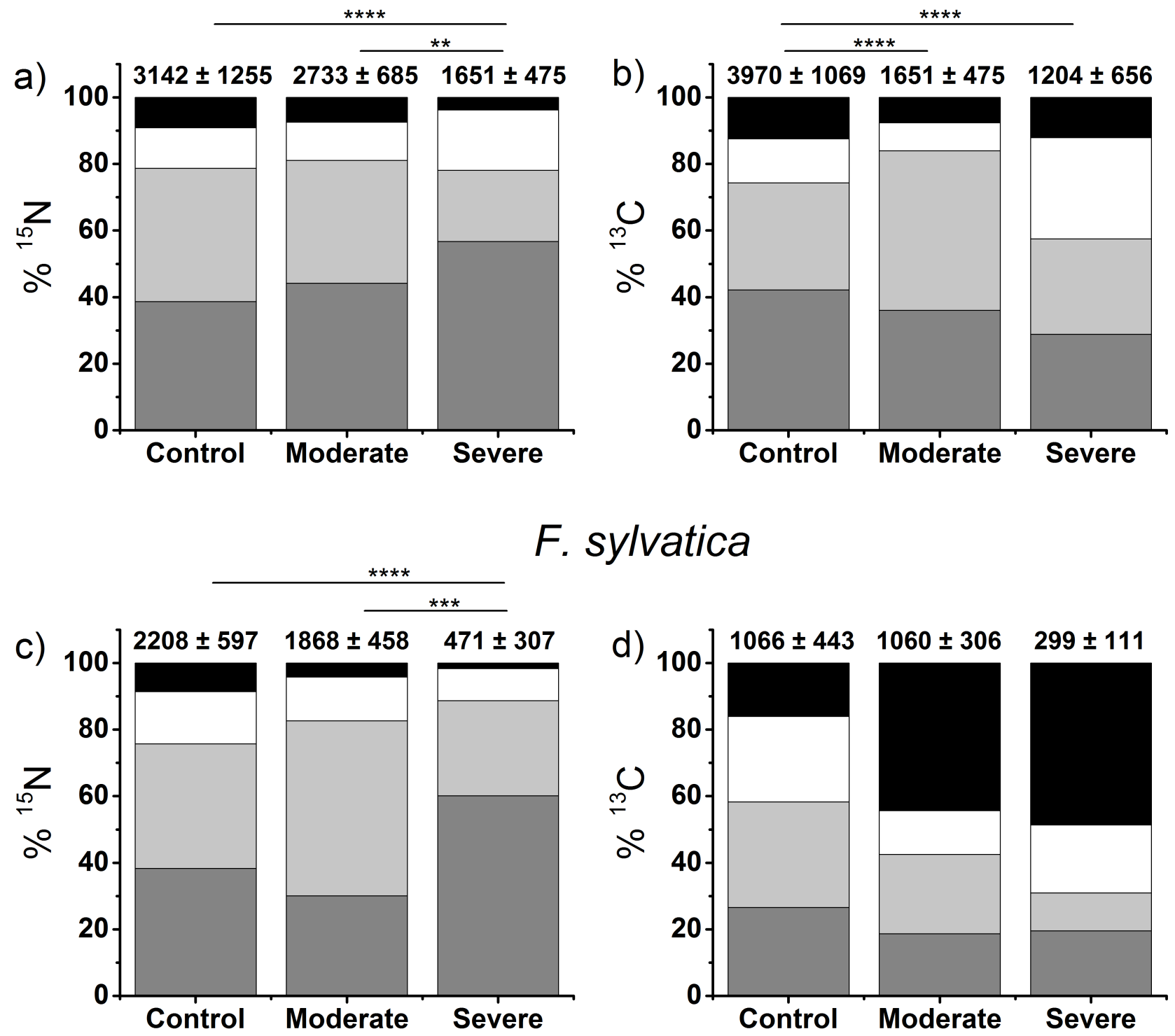

sylvatica

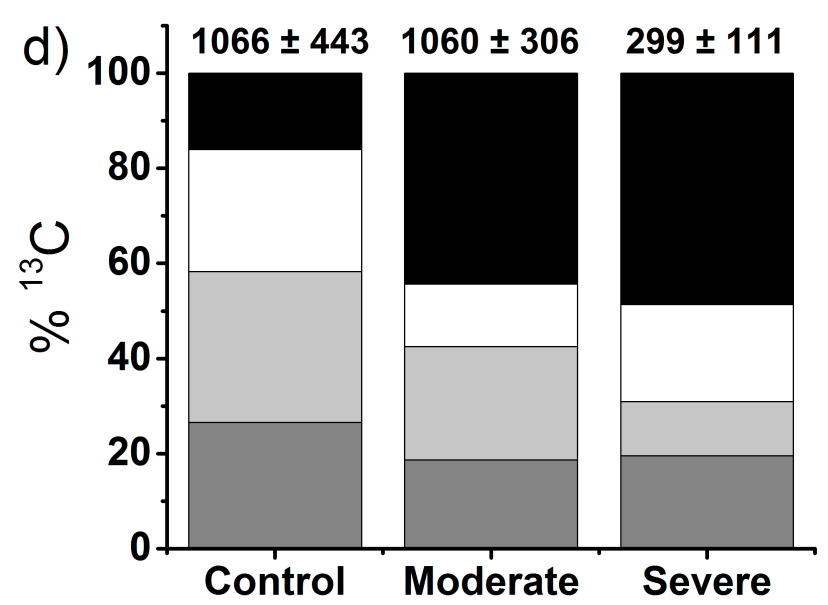

Q. petraea
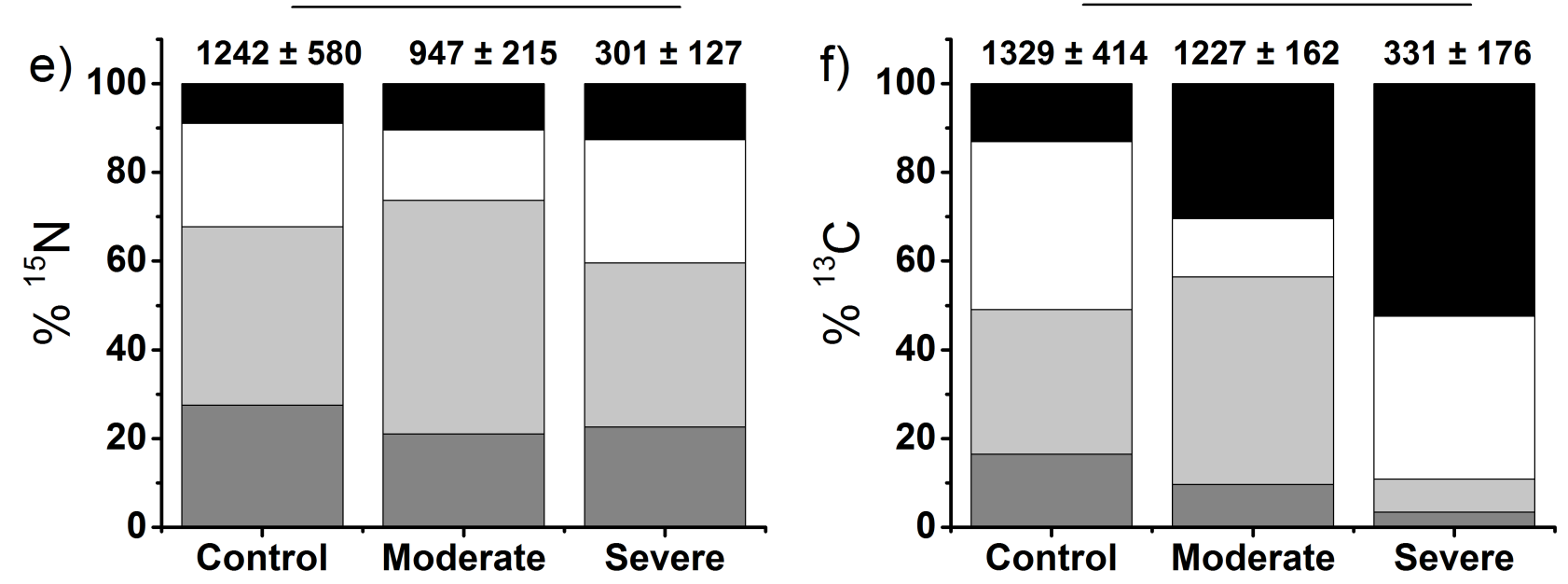

Drought treatment

Drought treatment 


\section{P. abies}
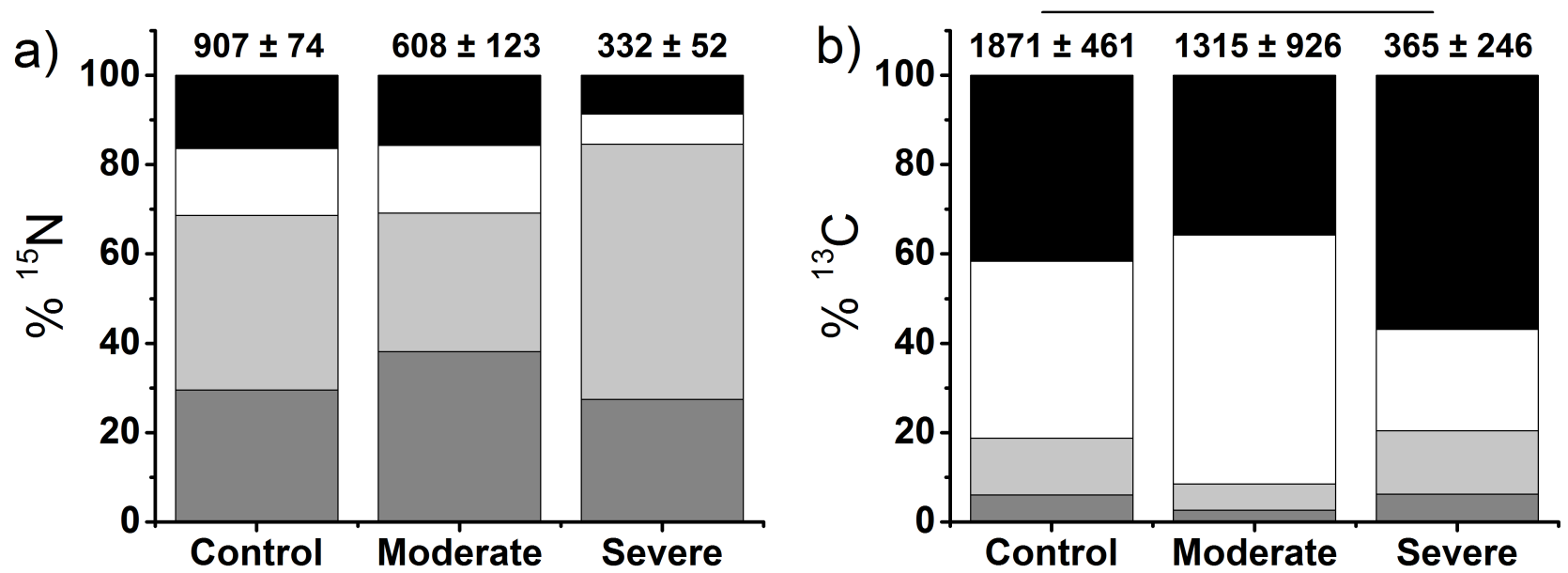

A. alba
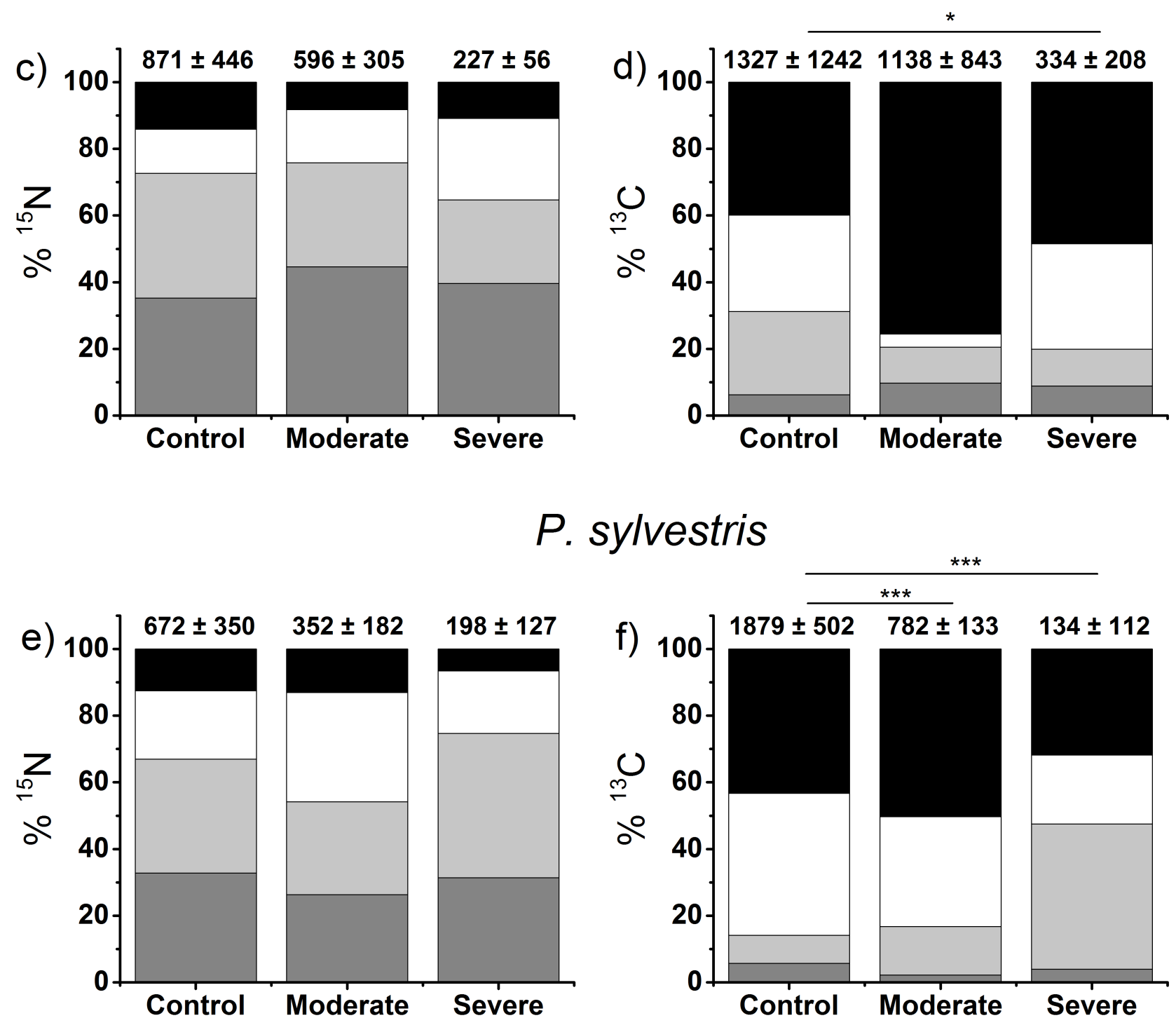

Drought treatment

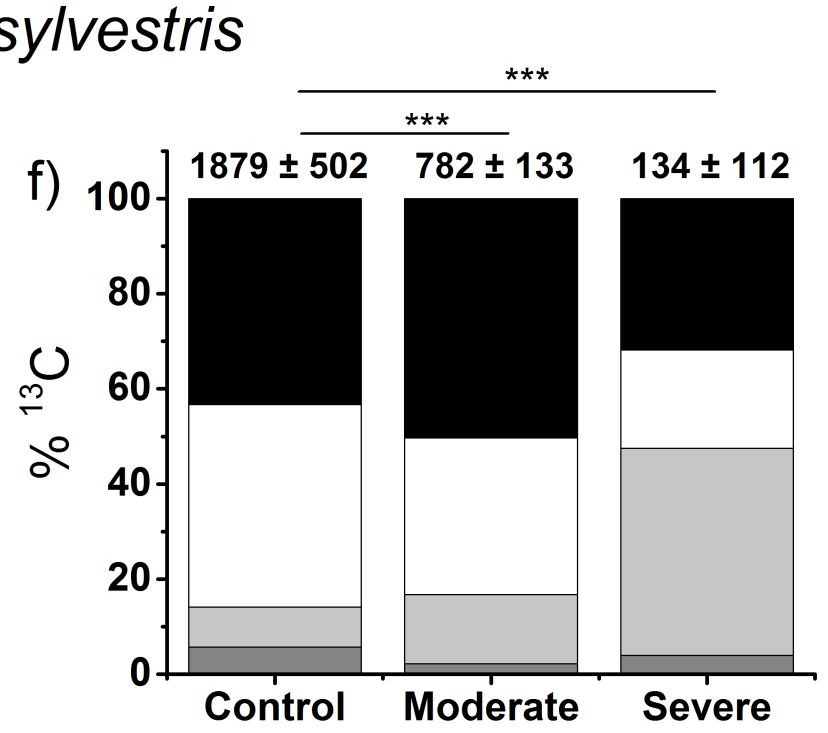

Drought treatment 


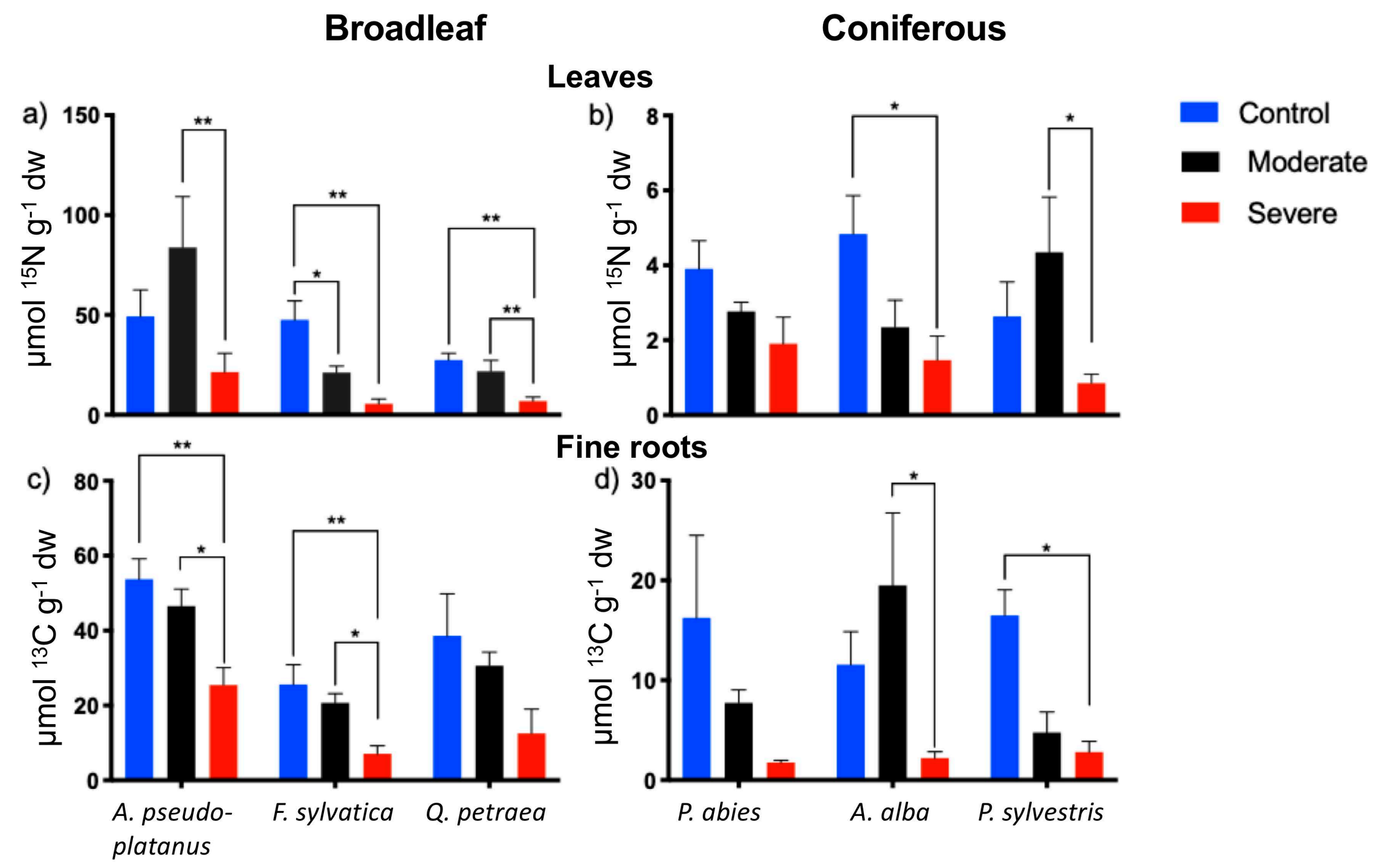




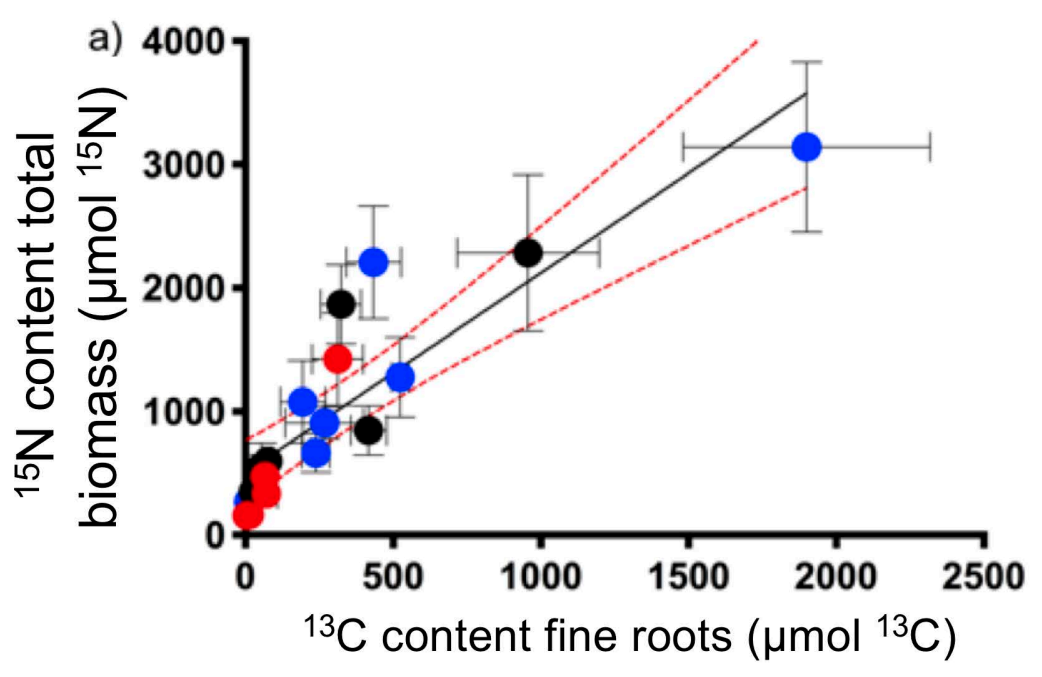

- Control

- Moderate

- Severe
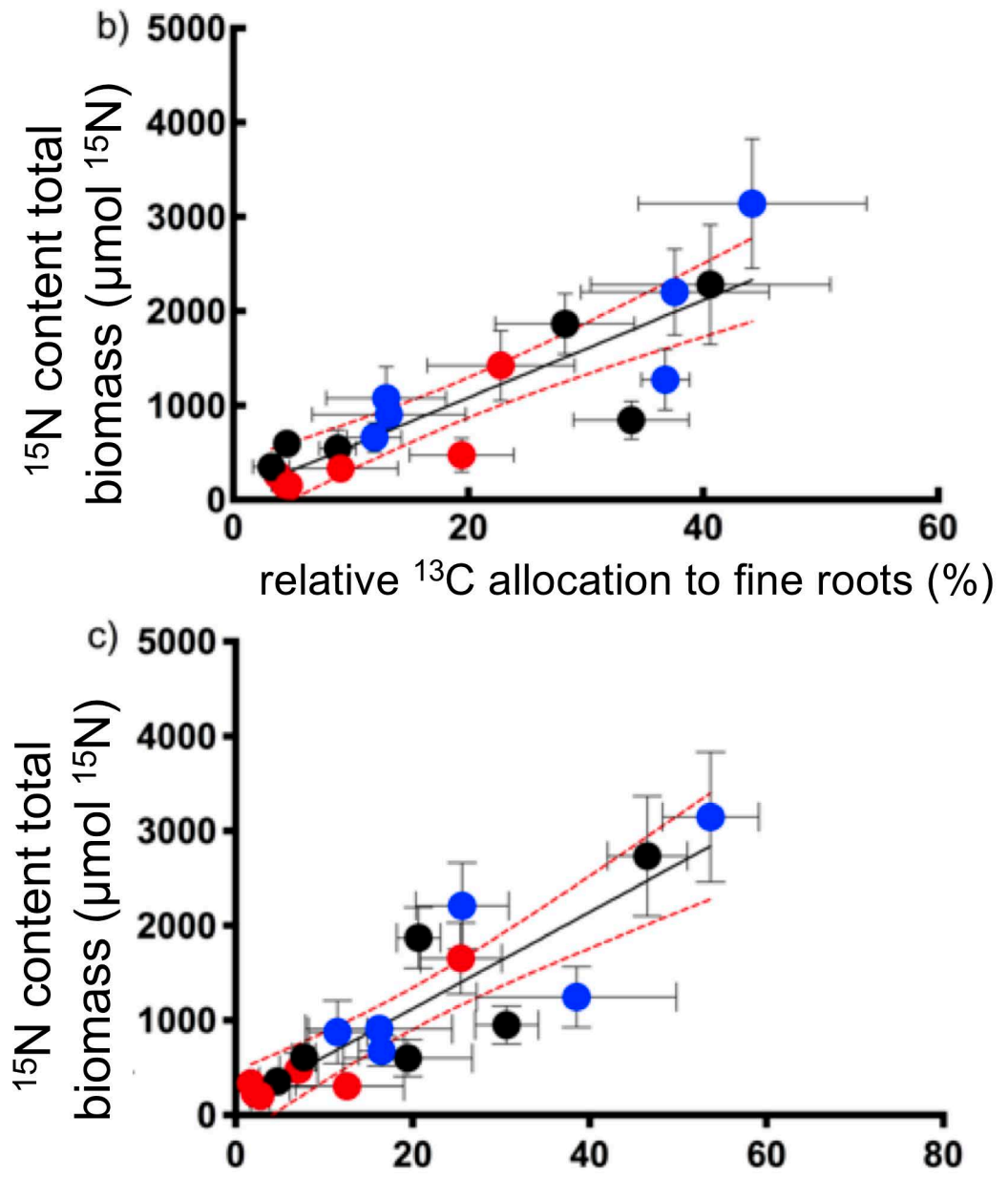

${ }^{13} \mathrm{C}$ concentration fine roots $\left(\mu \mathrm{mol}{ }^{13} \mathrm{C} \mathrm{g}^{-1} \mathrm{dw}\right.$ )

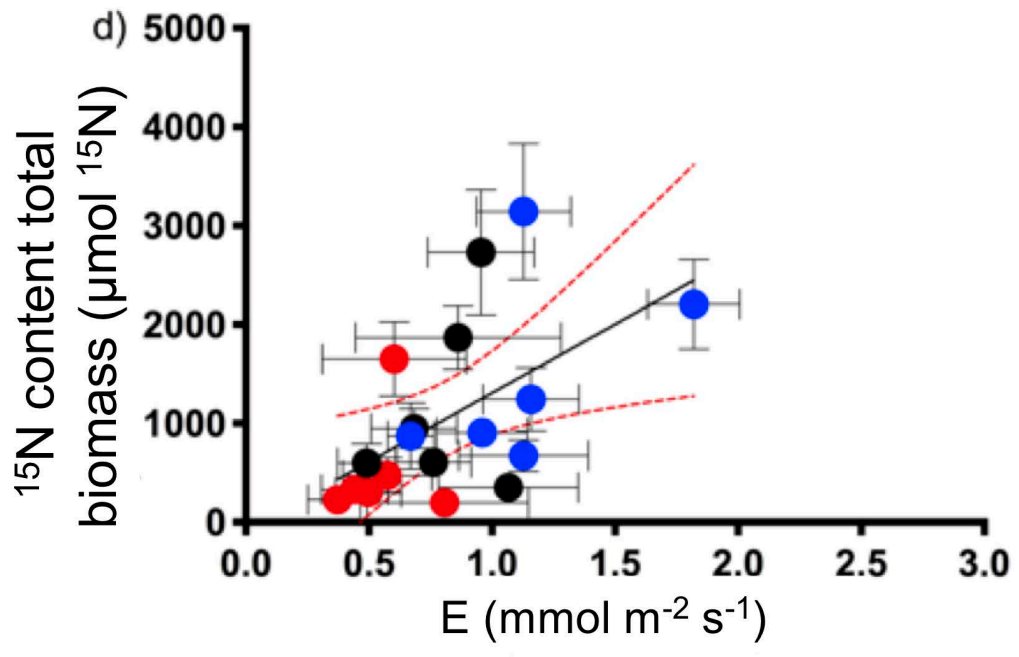




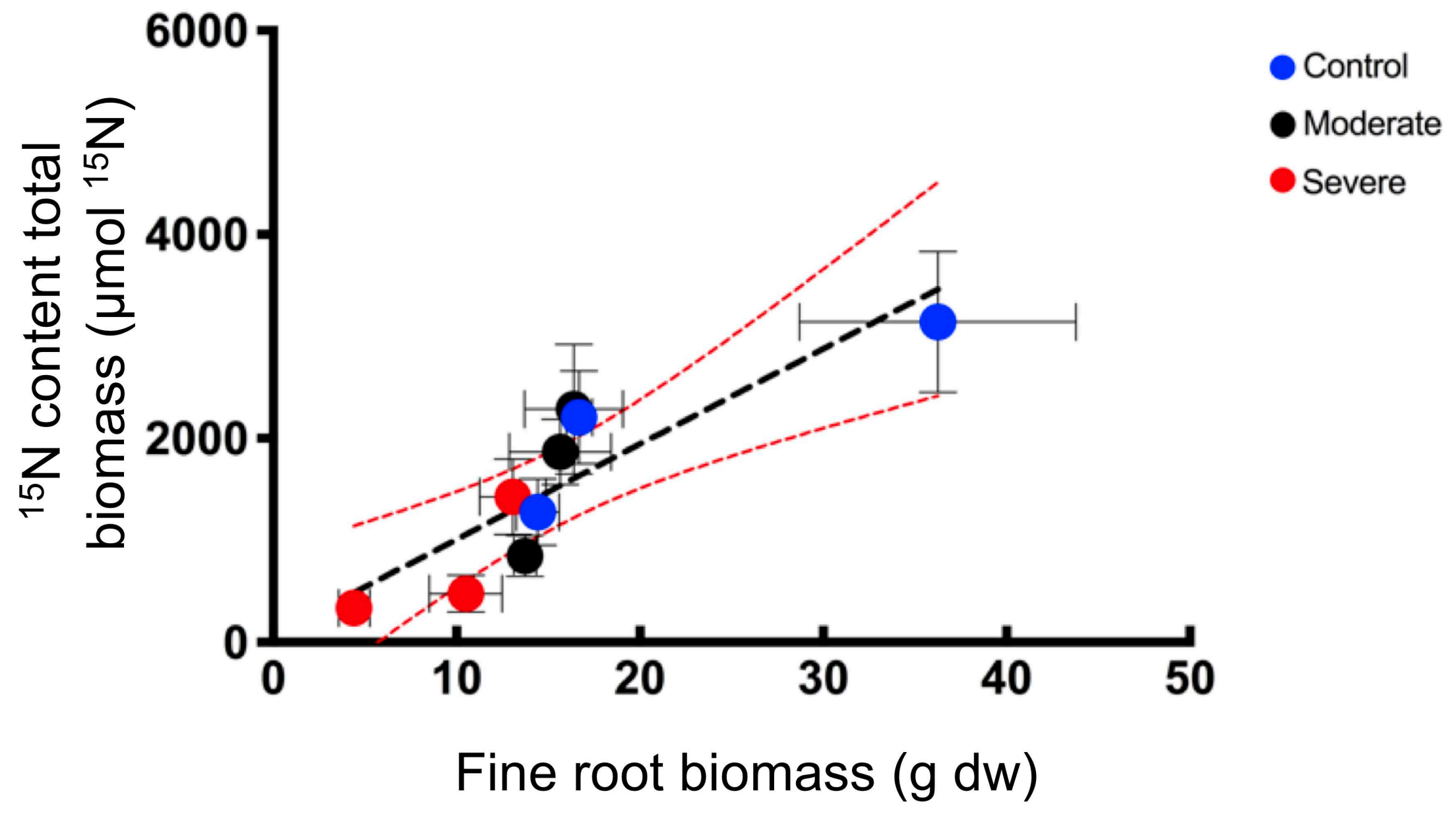



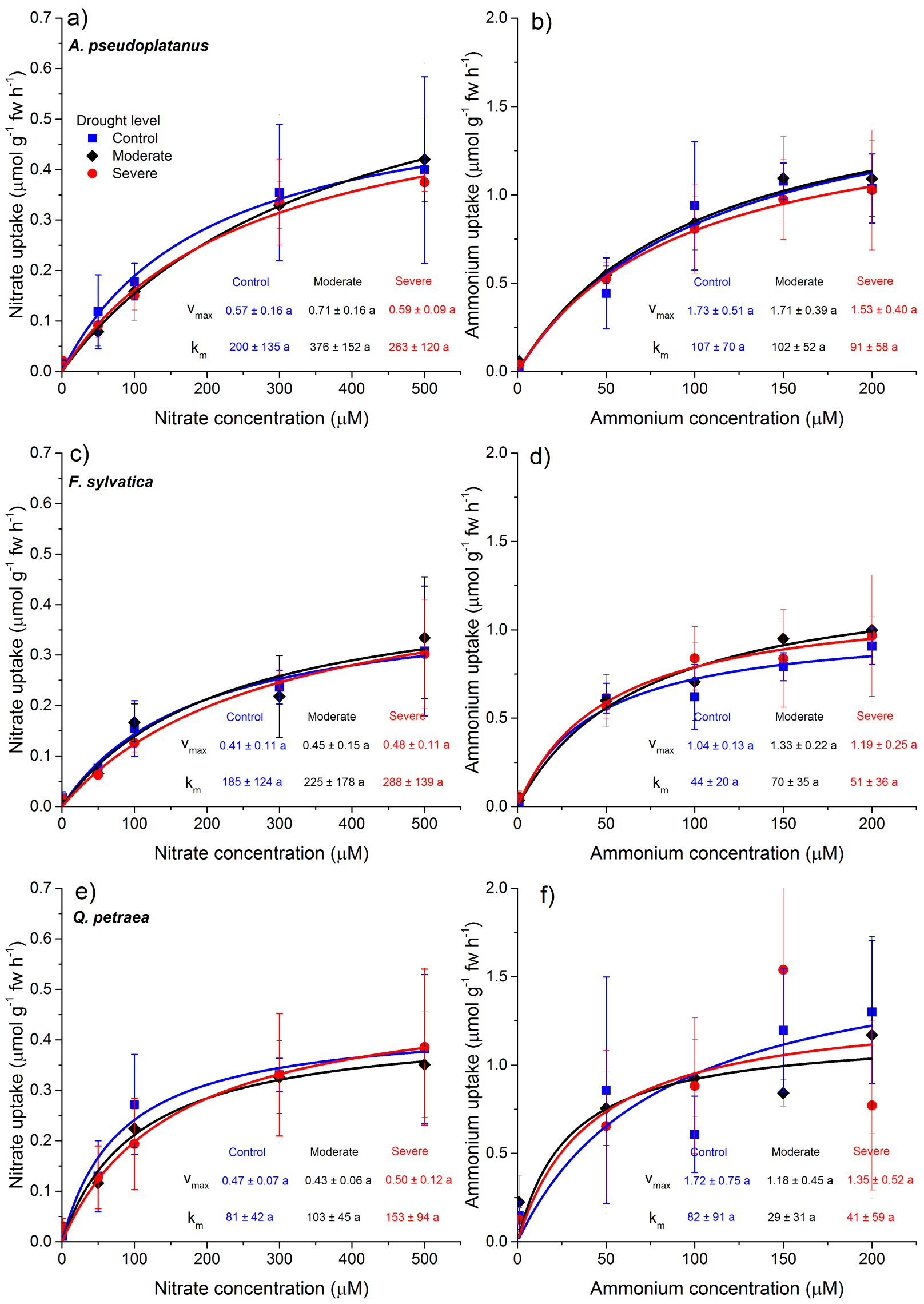

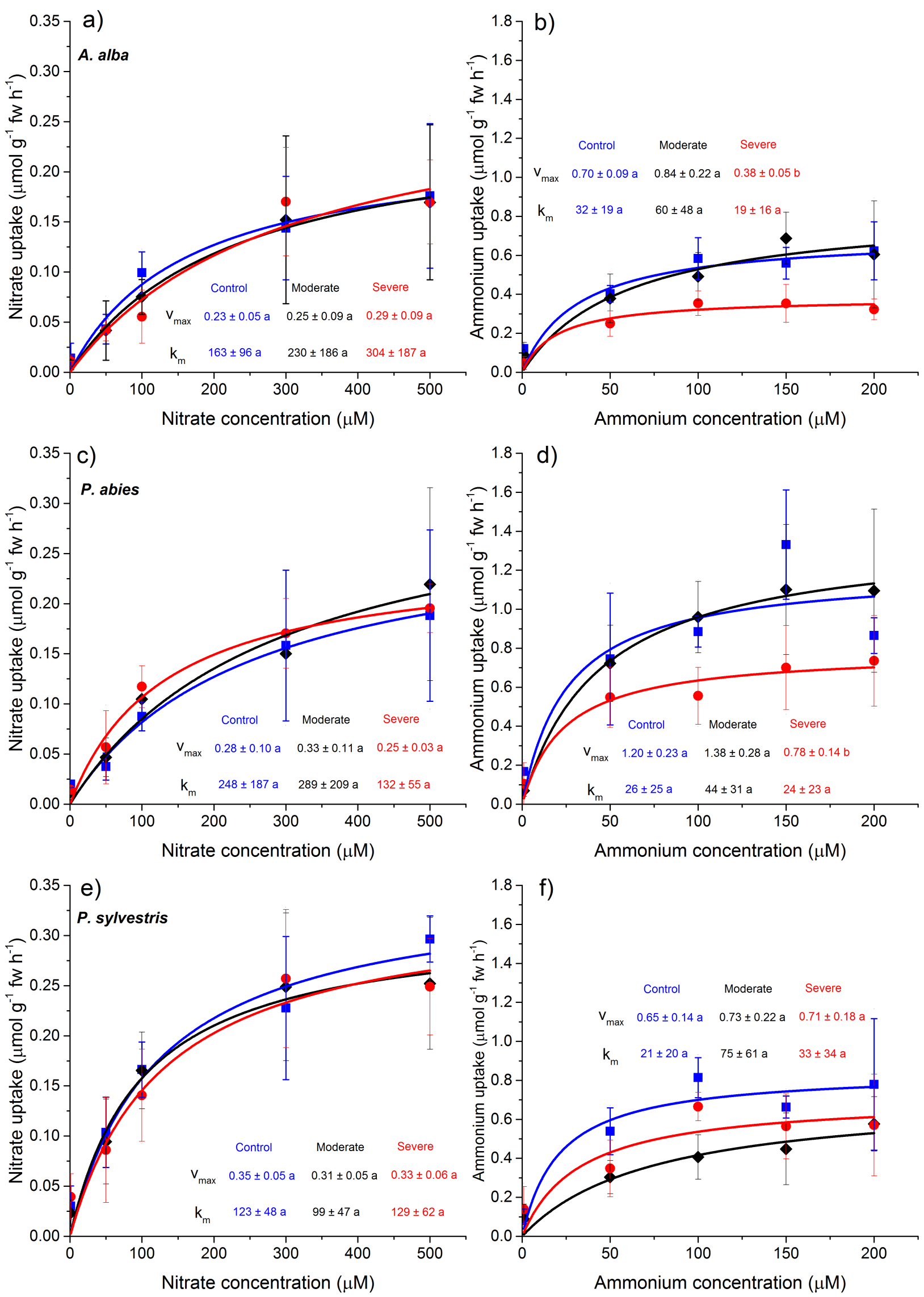

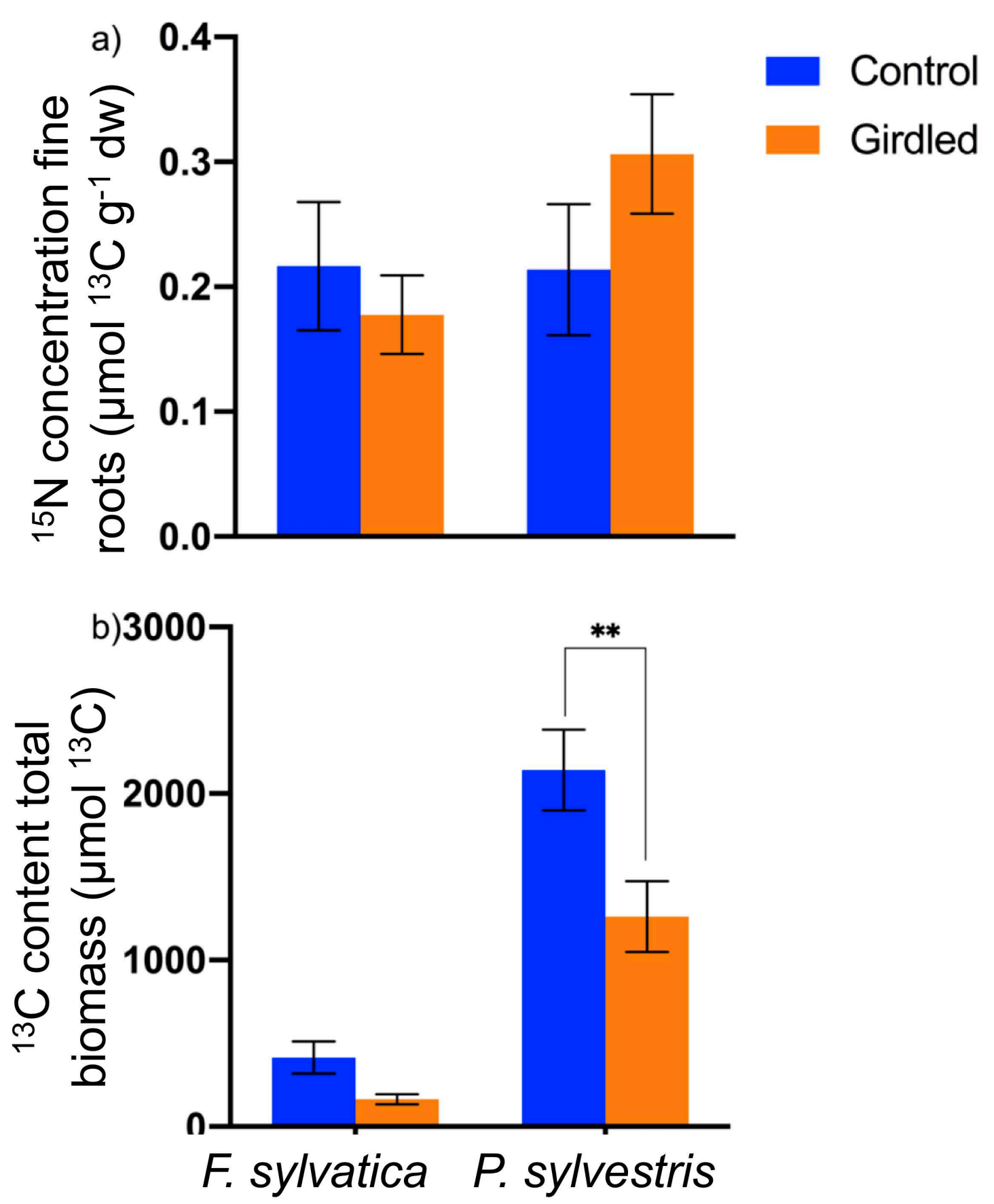
Table 1: Summary of leaf water potential (LWP), and gas exchange parameters during experiments i) - iii). Data (mean + SD) shown for leaf water potential (LWP), photosynthesis $\left(A_{\text {sat }}\right)$, stomatal conductance $\left(g_{s}\right)$, and transpiration $(E)$ are average values of measurements made during the respective treatments. Treatments in exp. i) and ii) were a moderate and a severe drought treatment including a well-watered control. In exp. iii) girdling and control treatments were compared. Statistical significance is denoted as different letters $(P>0.05)$ among the treatments based on 2-way ANOVA followed by either Tukey's or Dunnett's multiple comparison test.

\begin{tabular}{|c|c|c|c|c|c|}
\hline \multirow[b]{2}{*}{ Tree Species } & \multicolumn{3}{|c|}{ Exp i - ii) } & \multicolumn{2}{|c|}{ Exp iii) } \\
\hline & Control & Moderate & Severe & Control & Girdling \\
\hline A. pseudoplatanus & $-0.23 \pm 0.11^{a}$ & $-0.45 \pm 0.19^{b}$ & $-1.29 \pm 0.75^{c}$ & & \\
\hline F. sylvatica & $-1.36 \pm 0.61^{a}$ & $-1.9 \pm 0.81^{b}$ & $-2.34 \pm 1.23^{b}$ & $-0.74 \pm 0.48^{a}$ & $-0.82 \pm 0.45^{a}$ \\
\hline Q. petraea & $-0.25 \pm 0.12^{a}$ & $-1.02 \pm 0.58^{b}$ & $-1.35 \pm 1.10^{b}$ & & \\
\hline P. abies & $-0.46 \pm 0.12^{\mathrm{a}}$ & $-0.61 \pm 0.20^{a}$ & $-1.41 \pm 0.76^{b}$ & & \\
\hline A. $a l b a$ & $-0.30 \pm 0.10^{a}$ & $-0.82 \pm 0.35^{b}$ & $-1.38 \pm 0.78^{c}$ & & \\
\hline \multirow[t]{3}{*}{ P. sylvestris } & $-0.33 \pm 0.12^{a}$ & $-0.52 \pm 0.13^{a}$ & $-1.23 \pm 1.10^{\mathrm{b}}$ & $-1.0 \pm 0.11^{a}$ & $-1.24 \pm 0.17^{a}$ \\
\hline & \multicolumn{5}{|c|}{ Photosynthesis $A_{\text {sat }}\left(\mu \mathrm{mol} \mathrm{m} \mathrm{m}^{-2} \mathrm{~s}^{-1}\right)$} \\
\hline & Control & Moderate & Severe & Control & Girdling \\
\hline A. pseudoplatanus & $5.97 \pm 1.18^{a}$ & $4.48 \pm 2.35^{b}$ & $3.18 \pm 2.82^{\mathrm{c}}$ & & \\
\hline F. sylvatica & $6.73 \pm 2.31^{\mathrm{a}}$ & $3.99 \pm 3.33^{b}$ & $3.71 \pm 2.74^{b}$ & $3.14 \pm 0.71^{\mathrm{a}}$ & $2.03 \pm 1.55^{b}$ \\
\hline Q. petraea & $8.88 \pm 1.78^{a}$ & $5.22 \pm 3.64^{b}$ & $4.08 \pm 2.90^{\mathrm{b}}$ & & \\
\hline P. abies & $7.44 \pm 2.69^{a}$ & $5.69 \pm 3.28^{b}$ & $3.44 \pm 2.83^{c}$ & & \\
\hline A. $a l b a$ & $5.06 \pm 1.24^{\mathrm{a}}$ & $3.61 \pm 2.36^{b}$ & $3.02 \pm 2.36^{b}$ & & \\
\hline \multirow[t]{3}{*}{ P. sylvestris } & $6.38 \pm 3.49^{a}$ & $7.47 \pm 4.72^{\mathrm{a}}$ & $5.50 \pm 5.42^{b}$ & $9.79 \pm 4.77^{\mathrm{a}}$ & $7.28 \pm 2.49^{b}$ \\
\hline & \multicolumn{5}{|c|}{ 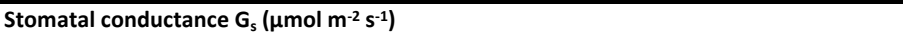 } \\
\hline & Control & Moderate & Severe & Control & Girdling \\
\hline A. pseudoplatanus & $111.3 \pm 25.82^{\mathrm{a}}$ & $84.04 \pm 41.19^{b}$ & $47.91 \pm 53.69^{c}$ & & \\
\hline F. sylvatica & $158 \pm 39.71^{\mathrm{a}}$ & $73.19 \pm 85.68^{b}$ & $48.34 \pm 39.73^{c}$ & $178 \pm 58^{a}$ & $159 \pm 46^{b}$ \\
\hline Q. petraea & $122.4 \pm 42.23^{a}$ & $56.99 \pm 36.32^{b}$ & $38.52 \pm 27.06^{c}$ & & \\
\hline P. abies & $70.76 \pm 43^{a}$ & $55.7 \pm 31.37^{a}$ & $26.18 \pm 21.21^{\mathrm{b}}$ & & \\
\hline A. $a l b a$ & $55.17 \pm 21.68^{\mathrm{a}}$ & $37.75 \pm 24.67^{b}$ & $29.75 \pm 24.81^{b}$ & & \\
\hline \multirow[t]{3}{*}{ P. sylvestris } & $92.46 \pm 50.66^{\text {aa }}$ & $77.68 \pm 39.22^{\mathrm{ab}}$ & $58.87 \pm 57.15^{\mathrm{bc}}$ & $128 \pm 66^{a}$ & $52 \pm 27^{b}$ \\
\hline & \multicolumn{5}{|c|}{ Transpiration E $\left(\mathrm{mmol} \mathrm{m}^{-2} \mathrm{~s}^{-1}\right)$} \\
\hline & Control & Moderate & Severe & Control & Girdling \\
\hline A. pseudoplatanus & $1.10 \pm 0.37^{\mathrm{a}}$ & $0.95 \pm 0.55^{\mathrm{a}}$ & $0.63 \pm 0.69^{b}$ & & \\
\hline F. sylvatica & $1.70 \pm 0.30^{\mathrm{a}}$ & $0.86 \pm 1.0^{\mathrm{b}}$ & $0.59 \pm 0.49^{b}$ & $2.4 \pm 1.1^{\mathrm{a}}$ & $1.8 \pm 0.79^{b}$ \\
\hline Q. petraea & $1.3 \pm 0.41^{\mathrm{a}}$ & $0.7 \pm 0.45^{b}$ & $0.49 \pm 0.32^{c}$ & & \\
\hline P. abies & $0.96 \pm 0.46^{a}$ & $0.78 \pm 0.38^{a}$ & $0.4 \pm 0.29^{b}$ & & \\
\hline A. $a l b a$ & $0.68 \pm 0.23^{a}$ & $0.48 \pm 0.29^{b}$ & $0.38 \pm 0.3^{b}$ & & \\
\hline P. sylvestris & $1.2 \pm 0.72^{\text {aa }}$ & $0.99 \pm 0.61^{\mathrm{ab}}$ & $0.83 \pm 0.93^{b c}$ & $13.16 \pm 2.45^{a}$ & $11.4 \pm 2.915^{b}$ \\
\hline
\end{tabular}

Table.2: Summary of growth parameters during experiments i) and ii). Data (mean + SD) shown for stem height, and stem diameter are average values of measurements made during 
last two weeks of respective treatments. Total biomass data have been determined on the day before pulse label application. Statistical significance is denoted as different letters $(P>0.05)$ among the treatments based on 1-way ANOVA followed by either Tukey's or Dunnett's multiple comparison test.

\begin{tabular}{|c|c|c|c|}
\hline & Control & Moderate & Severe \\
\hline \multicolumn{4}{|l|}{ Tree Species } \\
\hline A. pseudoplatanus & $79.51 \pm 7.04^{\mathrm{a}}$ & $69.86 \pm 3.07^{b}$ & $73.14 \pm 2.93^{b}$ \\
\hline F. sylvatica & $47.72 \pm 2.68^{\text {aа }}$ & $58.66 \pm 6.37^{a b}$ & $48.19 \pm 4.38^{\text {aa }}$ \\
\hline Q. petraea & $71.58 \pm 9.99^{a}$ & $69.97 \pm 9.05^{a}$ & $65.91 \pm 10.43^{\mathrm{a}}$ \\
\hline P. abies & $48.23 \pm 1.54^{\mathrm{a}}$ & $47.39 \pm 3.75^{a}$ & $46.19 \pm 1.72^{\mathrm{a}}$ \\
\hline A. $a l b a$ & $39.43 \pm 1.46^{a}$ & $42.34 \pm 3.49^{a}$ & $42.34 \pm 2.84^{a}$ \\
\hline P. sylvestris & $55.47 \pm 5.22^{\mathrm{a}}$ & $50.79 \pm 6.01^{a}$ & $48.83 \pm 6.14^{\mathrm{a}}$ \\
\hline \multirow[b]{2}{*}{ A. pseudoplatanus } & \multicolumn{3}{|c|}{ Stem Diameter $(\mathrm{mm})$} \\
\hline & $10.62 \pm 0.76^{\text {aa }}$ & $9.64 \pm 0.59^{\mathrm{bc}}$ & $9.95 \pm 0.84^{\mathrm{ac}}$ \\
\hline F. sylvatica & $10.39 \pm 0.50^{\mathrm{a}}$ & $10.71 \pm 0.65^{a}$ & $9.23 \pm 0.32^{b}$ \\
\hline Q. petraea & $9.307 \pm 0.86^{\mathrm{a}}$ & $8.927 \pm 0.31^{\mathrm{a}}$ & $9.35 \pm 0.44^{a}$ \\
\hline P. abies & $13.54 \pm 0.58^{\mathrm{a}}$ & $14.28 \pm 0.87^{\mathrm{a}}$ & $14.16 \pm 0.46^{\mathrm{a}}$ \\
\hline A. $a l b a$ & $12.2 \pm 0.63^{\mathrm{a}}$ & $12.34 \pm 0.44^{a}$ & $11.33 \pm 0.27^{b}$ \\
\hline \multirow[t]{2}{*}{ P. sylvestris } & $13.25 \pm 0.65^{\mathrm{a}}$ & $10.79 \pm 0.57^{b}$ & $9.97 \pm 0.19^{c}$ \\
\hline & \multicolumn{3}{|c|}{ Total Biomass (g) } \\
\hline A. pseudoplatanus & $85.29 \pm 21.28^{a}$ & $51.32 \pm 12.49^{b}$ & $41.66 \pm 5.76^{b}$ \\
\hline F. sylvatica & $42.24 \pm 3.95^{\mathrm{a}}$ & $41.09 \pm 3.20^{\mathrm{a}}$ & $25.73 \pm 3.45^{\mathrm{b}}$ \\
\hline Q. petraea & $42.97 \pm 12.70^{\text {aa }}$ & $33.45 \pm 4.16^{\mathrm{ab}}$ & $21.58 \pm 2.68^{\mathrm{bc}}$ \\
\hline P. abies & $83.47 \pm 56.88^{\mathrm{a}}$ & $79.85 \pm 49.06^{a}$ & $51.63 \pm 19.86^{\mathrm{a}}$ \\
\hline A. $a l b a$ & $100.31 \pm 38.56^{a}$ & $94.98 \pm 22.94^{a}$ & $70.42 \pm 11.31^{\mathrm{a}}$ \\
\hline P. sylvestris & $65.10 \pm 17.34^{a}$ & $31.04 \pm 6.11^{b}$ & $34.78 \pm 17.88^{b}$ \\
\hline
\end{tabular}

